\title{
Links between Maori Cultural Well- Being and Participation in Sports: A Literature Review
}

\section{INTRODUCTION}

The purpose of this literature review is to explore various dimensions of the relationship between participation by Maori in sports, the creation and maintenance of sustainable cultural infrastructures, and the contribution of these elements to an enhanced sense and practice of cultural identity. This is achieved through undertaking a qualitative survey of the present domestic literature on the topic, as well as drawing on the more extensive corpus of international research which addresses these types of topics, themes, and links.

The issue of cultural wellbeing has the potential for a profound impact on sustainable Maori success, which is one of the prescribed potential outcomes identified by Te Puni Kokiri for this research. This review will contribute to that process by providing specific analyses of the types of connections between participation in sports and the potential enhancement of cultural identity.

\section{Structure}

This review commences with a general introduction that prefigures some of the main themes that will be addressed, followed by the rationale behind the review, the methodological approach, and the definitions used. This is then succeeded by the five main sections of the review. 
The first of these sections deals with the present status of Maori participation in sport in the country, and related aspects of Maori demographics. This helps to establish the nature and context of the group under consideration, and produces a 'snapshot' of the current position of Maori participation in sports.

The following section examines the elements that constitute a sustainable cultural infrastructure - focussing on the whanau as the essential building-block of Maori society. It also evaluates the factors that contribute to Maori cultural sustainability.

The next section establishes some general traits in the nexus of sport and culture, and on the elements influencing this relationship. International data, particularly that relating to similar indigenous experiences in other countries, is drawn on to augment the review and as a means of producing more representative findings.

The penultimate section explores the implications of the previous data on the enhanced sense of Maori cultural identity that potentially stems from participation in sports, and contains a series of extrapolations that can be used as a basis for further planning on this topic.

The final section considers the means by which Maori involvement in sport can be enhanced in a manner that is beneficial to the cultural well-being of the individuals concerned. This section is followed by a glossary, the bibliography, and references in the form of endnotes.

\section{Methodology}

The resources relating to some of the relationships between sport and culture are comparatively weakly developed at present, especially within the domestic New Zealand context. Consequently, one of the functions of this review is to address the quality and relevance of resources on this topic, and enhance the provision of knowledge in an area where there is presently a clear deficit. 
The search strategy and selection criteria adopted for this review relies on utilising the existing body of research and literature relating to the main themes. However, there are some qualifications that are applied to their usage and interpretation. First, the majority of the research is correlational, and cannot therefore guarantee to determine 'cause and effect' relationships. To be more assured about causal connections, experimental manipulation of parenting factors under tightly controlled conditions can sometimes be attempted, but this sort of approach would not be feasible in social research of this nature. However, correlational research can be useful in demonstrating significant associations between culture, sport, and cultural identity at a thematic level, and such an approach is employed at relevant points at this review.

Most data that currently exists on Maori involvement in sport is quantitative in nature. There is only a small minority of studies - even internationally - that consider the connections between participation in sporting activities and the enhancement of cultural identity, particularly for indigenous groups. Also, some of these studies tend to have a 'pro-culture' bias, in that they deliberately attempt to create links where the empirical evidence would otherwise suggest that such connections are tenuous. This consideration tempers the analysis of some of the literature under consideration.

Much of the literature considered is also attached to other themes and topics, rather than being 'stand-alone' works specifically on the topics under review for this project. Therefore, there is some effort made at disentangling data from sources that might not immediately seem to be connected with the relevant topics.

Because some of the literature that is drawn on is derived from studies outside New Zealand, there are two guiding considerations when assessing and utilising this material. 
These are whether the patterns of sport and cultural identity are applicable only to specific cultures or countries, and whether there are external factors (population size, ethnic constitution of population, history and traditions of sport, and so forth), that are likely to impact on compatibility with findings in the international literature.

\section{Definitions}

Various terms appear in this review which, although in common usage, require specific semantic boundaries for the purpose of giving greater consistency and definition to the meaning of the text. Sport, in the context of this review, is defined as a physical activity that is governed by a set of rules or customs and often engaged in competitively. It can involve teams or be an individual activity with a competitive element. Moreover, it requires some form of physical exertion and skill as its primary prerequisite. ${ }^{1}$ The term sport was further delineated in the 1998 report of the Maori Taskforce on Sport, Fitness, and Leisure, convened by the Hillary Commission. It extended 'sport' to leisure and fitness, which were respectively defined as '...physical wellbeing resulting from participation in sport and leisure activities', and '...physical activities or physical pastimes engaged in New Zealand for the purpose of relaxation or enjoyment; and includes such physical activities or physical pastimes engaged in overseas by New Zealanders'. ${ }^{2}$ At a broader level, leisure activities centre around '.... freedom to pursue those things of interest to an individual'. 3 This lack of compulsion positions sports and leisure pursuits as a preference activity for participants.

Developing a description of cultural identity can be problematic, principally because the definition depends to such a considerable extent on the subjective views of individuals. Any attempt at fixing a meaning runs the risk of prescribing limits which may not fit everyone in the group under consideration. Consequently, the use of the term 'cultural identity' in this review is given definition by its 
particular usage in the relevant literature. Otherwise, its definition remains deliberately broad.

In the context of this review, the notion of sustainable cultural infrastructures focuses predominantly (though not exclusively) on whanau. Sustainability is defined - in terms of whanau participation - as a process in which the current and historical socio-cultural traits associated with whanau endure for subsequent generations.

The concept of whanau itself requires greater explanation. Walker describes whanau as traditionally being '...the basic social unit in Maori society...which would comprise up to three or four generations' living together simultaneously. ${ }^{4}$ It was also an extended family and social unit based on kinship ties, through a common ancestor, and built around a set of mutual obligations. ${ }^{5}$ However, following a period of rapid and substantial Maori urbanisation after the Second World War, accompanied by strong forces for assimilation, whanau concepts were modified in some instances. Onto traditional understandings of the role, constituency, and operation of whanau were grafted different sub-structures, often influenced by the fact that people from different whanau being unified through settling in new geographical areas. ${ }^{6}$ For the purpose of this review, whanau is assumed to be a broad entity, based on ancestral connections, but also (either alternatively or complementarily) on modern geographical or social collectives, or at its most extreme, simply a shared sense of belonging to the group. In this framework, the possibility for multiple whanau membership exists. Specifics on the roles and definitions of whanau appear in section 3.1 of this review.

\section{THE CURRENT 'STATE OF PLAY'}

One of the principal sources of information on the current state of Maori involvement in sports is the statistical data produced by Van Aalst, Kazakov, and McLean for Sport and Recreation New Zealand. ${ }^{7}$ This remains the most 
comprehensive and most recent analysis of involvement and trends for sports participation in the country. Furthermore, in many cases, the data has been collected in such a way as to allow comparison of Maori and non-Maori in various criteria. The following material in this section summarises some of the key findings of the report in order to provide an overview of Maori involvement in sport, and to set the context for the ensuing review of literature related to this involvement.

Among young people, Maori and European rates of activity ( $71 \%$ and $70 \%$ respectively) are around the same, and this pattern of similar levels of activity continues into adulthood (67\% and $69 \%$ respectively). ${ }^{8}$ Maori are more likely to participate in a sporting activity than any other group, and are also more likely to belong to a sports club, and have received some coaching or instruction. ${ }^{9}$ However, it is noted that among groups considered to be inactive or sedentary, Maori have the highest rates in the $18-24$ years age group. In the following age group ( $25-34$ years) these inactivity levels drop, although to a lesser extent than for other ethnic groups. ${ }^{10}$ Maori youth have the highest rate $(66 \%)$ of interest in taking up a sport of any of the ethnic groups surveyed - a figure which applies to both male and female respondents. ${ }^{11}$

When it comes to where participation in sports takes place, for Maori youth, 92\% were involved in some form of sport of physical activity, of whom $72 \%$ participated at school during school time, 23\% participated at school, but either before or after school, $29 \%$ with a club, and $67 \%$ with family and friends. ${ }^{12}$

Over the period of one year, $87 \%$ of Maori had participated in at least one sporting activity, with an average of 5.7 participation events, spread over an average of 2.9 different sports. ${ }^{13}$ The top fifteen sports for Maori adults, with their percentage levels of involvement, were: touch rugby (25\%); golf (16\%); netball (16\%); rugby union (13\%); basketball $(13 \%)$; rugby league $(10 \%)$; tennis $(9 \%)$; cricket $(8 \%)$; volleyball $(6 \%)$; 
softball (6\%); motor sports (6\%); squash (5\%); shooting (5\%); equestrian (5\%); and soccer (4\%). ${ }^{14}$

As far as trends are concerned, there has been little substantial change in overall Maori levels of physical activity since 1997. Although there was an increase in activity among young Maori between 1997 and 2001, this was offset by an increase in inactivity by Maori aged over fifty. ${ }^{15}$ The influences on Maori choosing to increase activity levels were also surveyed, and revealed that magazines, newspapers, books, and brochures were the biggest single influence $(37 \%)$, followed by television advertising and programmes (22\%), and word of mouth (13\%). ${ }^{16}$

\section{SUSTAINABLE MAORI CULTURAL INFRASTRUCTURE AND MAORI WELL-BEING}

When considering what constitutes sustainable Maori cultural infrastructure, the whanau has been identified in the bulk of the literature as the basis of Maori cultural infrastructure. ${ }^{17}$ The brief definition of the whanau has been provided in the introductory section of this review, but it is important to explore the purpose and functions of whanau in order to evaluate how they might contribute to Maori well-being.

\section{Whanau as the Core of Maori Cultural Infrastructure}

Moeke-Pickering's 1996 work on Maori identity within whanau provides a comprehensive assessment of - among much else the role of whanau as the essential building-block of Maori society, and as a unit almost purpose-designed to promote Maori well-being. ${ }^{18}$

Traditionally, the whanau was the place where initial teaching and socialisation of things Maori took place. More than an extended family social unit, the whanau was based on kinship ties, shared a common ancestor, and provided an environment within which certain responsibilities and obligations were maintained. ${ }^{19}$ However, in modern, post- 
industrial New Zealand, the approach to and understanding and experience of whanau has become much broader. MoekePickering cites research which shows that While the traditional whanau arrangement and its related obligations and responsibilities to hapu and iwi was appealing to some Maori, for other Maori choosing a type of family arrangement that suited individual and family preferences was more logical given the economic driven environment. The location, nurturants, socio-economic realities and exposure to traditional cultural practices influenced somewhat how each individual and whanau formed and maintained their Maori identity'.20 And while Durie acknowledges that '...there is no single exact measure of what constitutes Maori identity', ${ }^{21}$ Moeke-Pickering observes that there is some fluidity in the current understanding of Maori identity: '...that Maori identity is still being asserted today means that the shaping of Maori identity is still occurring'. ${ }^{22}$

Whanau definitions can loosely be placed into three categories. The first is the traditional model, in which '...identity was derived from membership and learning within the whanau, hapu, iwi and waka',23 and in which 'The individual was able to maintain their sense of belonging through their capacity to whakapapa or find genealogical ties to each of these structures within which certain responsibilities and obligations were maintained'.24 Broughton and Rangihau emphasise the importance of whanau as socialising and acculturising agents: 'Cultural practices such as language, customs, kinship obligations and traditions were fundamental to the socialisation of Maori identities'.25 Traditional whanau structures, according to Moeke-Pickering, '...intertwined with the cultural practices provided the pathways through which Maori identities could be formed and developed'. 26

The next category of a whanau is the transitional one, in which the effects of colonisation begin to become apparent on the traditional whanau model - leading to corresponding 
changes in Maori identity. Although not always overtly labelled as such, this transitional phase is evident through the perspectives of writers, many of whom who have described whanau from their own experiences being brought up in one during the twentieth century. John Rangihau, for example, conveyed his understanding of developing a Maori identity through whanau membership which took place in spite of a dominant Pakeha culture surrounding the whanau. Thus, he emphasised his perception of Maori identity as involving '...growing up in a Maori community; earning apprenticeships by participating, learning the kawa, customs and traditions that are part of being of a particular tribal group'. ${ }^{27}$ Ranginui Walker,28 Manuhuia Bennett, ${ }^{29}$ Rangimarie Parata,30 Timoti Karetu, ${ }^{31}$ similarly base their presentations of what constitutes a whanau substantially on their own experiences of being in whanau that exist like islands in a sea of Pakeha culture.

The third category of whanau exists in an unashamedly modern setting. Moeke-Pickering draws attention to the view expressed by Durie, Black, Christensen, Durie, Taiapa, Potaka, and Fitzgerald that '...we should not rely solely on those traditional tribal structures of whanau, hapu, iwi and waka to determine Maori identity. Instead, social, economic and lifestyle characteristics, ecological and social influences such as changing demographic patterns, cultural beliefs and technological advancement need to be taken into consideration to provide a more reined understanding of Maori identity'. ${ }^{32}$

It is the modern whanau, and its potential role in the sustenance of Maori culture, the well-being of Maori, and the possible interaction of these two functions with participation by Maori in sport which is the primary focus of this section of the review. Contemporary whanau did not suddenly emerge in modern, post-industrial New Zealand society, so in one sense, they are not so much modern as they are the modern mutation of a traditional, pre-European form of familial, economic, and social organisation. ${ }^{33}$ The new form of whanau was influenced largely by the circumstances of Maori 
urbanisation, which meant '...that a number of Maori were not exposed to maintaining and organising themselves primarily around their whanau, hapu, and papakainga'. ${ }^{34}$ Nor did they know their genealogical ties, ${ }^{35}$ or have a contact person who could assist with the continuity of whanau ties. ${ }^{36}$ Some whanau did persist with the traditional ways to the best that circumstances permitted, but a survey of one hundred Maori households conducted by Walker in 1969 revealed that '...90 were single family units. Small houses and confined space made it difficult to continue the extended family, except in a modified form such as the mini-marae.... So the norm was a single family unit to a single dwelling, with each family responsible for its own economic well-being' ${ }^{37}$

In such situations, it is not difficult to see how sporting activities, and especially team sports, would be an effective means of reviving some of the whanau spirit that was lost through urbanisation. Thus could sports serve a cultural function as a preserve of some of the essence of the 'whanau feeling' - including unity, commonality of purpose, and social and cultural exchange and maybe even reinforcement.

The irony of the trend away from whanau is that by the 1990s, single-family households were more common proportionately - among Maori than non-Maori.38 However, the predominance of Maori in single-family households does not mean that the whanau spirit has been abandoned. 39 'Some Maori families', observes Moeke-Pickering, '...have become competent at maintaining a balance between economic circumstances and keeping continuous their whanau and tribal practices. However, for other Maori families, maintaining an ethnic Maori identity may be what is desirable, and in some cases all that their resources can allow at this time'. ${ }^{40}$ This spectrum of whanau participation and identity is mirrored in other aspects of Maori identity, and therefore suggests that an equally broad-spectrum approach to recognising and planning for Maori involvement in sport is required. 
Another aspect of whanau is that it can relate directly to both cultural identity and Maori participation in sport. Moeke-Pickering cites a 1993 interview between Keith Quinn and Buck Shelford, in which these links were made explicit: 'Like many others, Buck Shelford is at a bit of a loss trying to pinpoint the essence of Maori rugby. He knows from his years of experience there's something special about it. But it's hard to define. Then, after some hesitation, he settles on "whanau" as the unique ingredient. His explanation? "The bond a Maori feels when he's with his family or with his friends in a rugby team, the whanau, makes him uninhibited on the field. Then, with this togetherness, the Maori likes to play with freedom. The whanau feeling makes the Maori better at team games than he or she is at individual games. The Maori likes the role of being in a team'.41 The significance of Shelford's inclusion of the term 'whanau' is that it serves as a '...management framework was to assist, organise and understand people. Although whanau as a management framework operates on similar principles to that of the tribal structures, descent to a Maori tipuna is not necessarily the primary factor. Utilising the concept of "whanau" provides for an environment in which meaning and belongingness can be nurtured'. ${ }^{2}$

\section{The Sustainability of Cultural Infrastructures}

While the whanau may be the backbone of Maori cultural identity, ensuring the sustainability of this infrastructure also warrants consideration. Durie has identified globalisation as an important factor bearing down on understandings of indigenous cultural infrastructures, including whanau, and suggests that one of the best responses to globalisation pressures is for indigenous peoples to take control of their own lives and destiny through some form of strategic direction. ${ }^{43}$ This reasserted control can then be used as a means to '...empowerment, less dependency, and more active 
engagement and participation in planning, policy and research'.44 Sport comfortably fits into this strategy as a mechanism for such empowerment. White describes the overall notion of Maori sustainable development as a process of '...cultural revitalisation, resilience, and the building of human and social capacity', 45 rather than an end-point which, once reached, as no room for further growth. Harmsworth's assessment of this process-based approach closely matches that of White's, but with an added international perspective. He sees the holistic approach to the sustainable development of a Maori cultural infrastructure as a '...constructive attempt to tackle the effects of globalisation from the perspective of a minority culture'. ${ }^{46}$ Ironically, this definition suggests that sport could potentially be a means of encouraging the globalisation of Maori and participation in the majority culture as much as a way of enhancing indigenous cultural identity and well-being.

\section{Maori Well-Being - Perceptions and Achievement}

Maori well-being is more than simply the absence of poor health. ${ }^{47}$ It is an holistic concept that captures cultural, physical emotional and spiritual dimensions. Palmer cites subsequent well-being measures that have emerged in the last four decades, and which are based on the notion that wellbeing can be measured by the predominance of good feelings over bad. ${ }^{48}$ To this very general approach has been added an emerging emphasis on psychological well-being. In Maori communities, Palmer points to the concept of well-being as being '...irrevocably tied to the resolution of land and sovereignty issues, balance between the physical and spiritual realms and protection of Maori identity'.49 The 1988 Royal Commission on Social Policy identified four components that it stated were pre-requisites for Maori well-being. These were '...whanaungatanga (family), nga taonga tuku iho (ancestral treasures), te ao turoa (Maori estates), and turangawaewae 
(ancestral land)'.50 Pere has augmented this description using the octopus (te Wheke) as a metaphor to '...symbolise the dynamic, multi-faceted and interrelated nature of Maori wellbeing'. ${ }^{51}$ Other models have also been introduced in the last two decades which are essentially variants of a common theme. ${ }^{52}$ As Palmer has noted, there is now '...a consensus on the importance of whanau, wairua, hinengaro and tinana [for Maori well-being]. In addition, each model has been built around the principle of inter-relatedness, coexistence and symbiosis. It seems the components of Maori wellbeing are not independent, separate or distinct entities but the product of co-relationships, connectedness and mutually beneficial dependencies'.53 Similarly, Harmsworth has concluded that Maori well-being can be assessed through '...standards of health, increased human and social capacity, strength of cultural identity, sustainable management of natural resources, and culturally appropriate strategies for economic growth. Central to this holistic development are Maori values, a strong sense of cultural identity and purpose, and the retention and use of Maori knowledge'. 54

Harmsworth goes on to identify the specific set of principles that he perceives lie at the heart of Maori well-being. These include: Iwitanga: (e.g., Ngati...tanga, Ngai...tanga, Te...tanga): expression and celebration of those qualities and characteristics that make an iwi or hapu unique and underpin a shared whakapapa, history and identity; Whakapapa: genealogical descent, heredity, lineage. The ordered relationship, structured lineage, and descentency from the universe, through atua, to land, air, water, and people; Tino Rangatiratanga, Rangatiratanga, Mana Motuhake: acts of authority, self-determination, and power; Mana Whenua, Mana Moana: legitimacy to control, manage, and administer land, water and marine resources; Manaakitanga: reciprocal and unqualified acts of giving, caring, hospitality; Arohatanga, Aroha: care, love and respect; Awhinatanga: assist, help, care for, give assistance and help to others; Whanaungatanga: the 
bonds of kinship that exist within and between whanau, hapu, and iwi, belonging, togetherness, relatedness; Whakakotahitanga, kotahitanga: respect for individual differences and the desire to reach consensus, unity, solidarity; Koha, Whakakoha, koha: acts of giving; Tau utuutu: acts of always giving back or replacing what you take or receive, reciprocity; Whakapono: act of believing or having faith and trust in others, or in a system or organisation; Wehi: reverence, act of being in awe; Turangawaewae: having a place of standing, belonging, and security; Kaitiakitanga: stewardship or guardianship of the environment; Kokiri: an act of going forward, being competitive; Te Aoturoa: the interdependence with the natural environment, the cosmological relationship and responsibilities of Maori in relation to the whole and parts of the environment; Taonga tuku iho: (e.g., te reo Maori, wahi taonga, taonga whakairo): the notion of recognising and holding on to the treasures and knowledge passed on from ancestors. Includes preservation of taonga to look after, house, protect, and manage taonga, such as natural resources, te reo Maori, and whakairo on behalf of iwi, hapu, and whanau; and Wairuatanga: the spiritual dimension'.55 The various permutations of these aspects of Maori well-being are said to act as a 'guiding philosophy' for the sustainable development of the Maori cultural infrastructure. 56

In July 2003, Creative New Zealand hosted what it called a 'Think Tank', the purpose of which was to explore how local authorities might fulfil their requirements under the Local Government Act to promote cultural well-being. Based on previous research, it was concluded that Maori well-being included Maori having '...a secure cultural identity and freedom of cultural expression, strong connections and ties to the Maori community, having the knowledge, skills and competencies to achieve the kind of life one chooses to live, and having the respect and goodwill of mainstream society'. ${ }^{57}$ These elements reflect the general consensus of what 
constitutes Maori well-being. This well-being can be integrated into concepts of Maori cultural sustainability, utilising the whanau as the central entity to achieve advances in both domains. The significance of the Creative New Zealand submission to the conference was that it made the connection between the theoretical perspectives on Maori cultural sustainability and well-being, and the practical possibilities for implementing these ideas. ${ }^{58}$ Sport, however, was excluded from consideration by Creative New Zealand, although leisure - which is a conceptually close form of activity - was recommended as a device to achieve these aims.

Another step on the path to achieving enhanced sustainable Maori cultural infrastructure and associated wellbeing was outlined by Harmsworth, Barclay, Kerr, and Reedy in 2002. It was based on the need to foster understanding in the dominant Pakeha culture, and emphasised the following points: 'Human/Social: understanding human resources, people resources, human capital, human capacity, human capability, he tangata he tangata; Cultural: understanding cultural resources, cultural vibrancy, cultural integrity, Maori values, tikanga Maori; Physical: understanding physical resources, natural resources, access to natural resources, physical state and condition, land and coastal characteristics, condition, and use, mana whenua, awa, moana, etc.; and Economic: understanding available economic resources, economic capital, investments, economic potential'. 59

In order to assess how these ideas and philosophies about Maori well-being and sustainable cultural infrastructures integrate with participation in sport, it is first necessary to understand some of the issues that surface when sport and culture are brought together. This is the focus of the next section. 


\section{THE NEXUS OF SPORT AND CULTURE}

The strands linking sport and culture are entwined with numerous other themes. Maguire has provided a broad parameter for and discourse on sport and culture, observing that '...studies of sport that are not studies of the societies in which sports are located are studies out of context....emphasis is...placed on the need to examine the interconnected political, economic, cultural and social patterns that contour and shape modern sport. Attention has also to be given to how these patterns contain both enabling and constraining dimensions on people's actions'.60 This section addresses some of these links between sports and elements of culture and cultural identity.

\section{Maori Participation in Sport: An Historical Overview}

The connection between Maori, whanau, and sport is one with a long pedigree, extending well before European intervention. The maintenance of physical fitness, according to some anthropologists, was always important to Maori: 'Centuries-old myths attest to the great pride the Maori had in the body. Physically fit men were permitted to marry and become fathers while ill-health was a disgrace. Many of the unique games recalled in the myths have all but disappeared since the arrival of the European'.61 Elsdon Best concluded that a number of activities carried out in traditional Maori society, including, '...(i) Military exercises and games viewed as useful training (wrestling, boxing, jumping, foot racing and tree climbing). (ii) Aquatic games and pastimes (swimming, surf riding and waka racing). (iii) Agility or manual dexterity games (dart throwing and jackstones). (iv) Games and pastimes of children (flying, toboggaining, top spinning and possibly stone bowling)', could be classified as sporting pursuits. ${ }^{62}$ Using the extended definition of sport, the 2001 Ministerial Taskforce on Sport observed that in most of the activities Best described, there were '...elements of ritual, training, defence and games. 
Physical activities were often referred to as "nga mahi a te rehia" or "the arts of pleasure". Maori tradition recounts legendary swimming and athletic feats which echo those found in all societies. In iwi settings there was little leisure, but the activities that may be considered in that context include weaving, action songs and haka, carving and poi. These were integrated with many dimensions of Maori life'.63 Thus, any consideration of Maori, sport, and culture needs to have traditional Maori culture as its starting point. What European intervention did was simply to extend the range of sports available (although probably eliminating some traditional Maori sports in the process) ${ }^{64}$ and to more strictly codify sporting activity.

With the onset of more substantial European (predominantly English) settlement, in the early nineteenth century, sports such as cricket were introduced (1825), along with the sort of competitive physical activities - including ploughing, wood chopping, mustering, and sheep shearing which represented the predominance of manual, land-based activities in pioneering life. 65 The colonial cultural influence on sports was considerable. Holliman argues, for example, that 'In a young country, colonial in character and dependent by necessity, the seeping influence from the mother country determines to a large extent the nature of subsequent development....Sporting practices are part of the cultural inheritance, and the games and pastimes which are adopted reflect essentially the sporting characteristics of the mother culture'.66 The consequence in New Zealand was an initial eagerness by some Maori to adapt to European sporting activities, as Miller glimpsed in the 1850s: 'The Maori likes to partake of the amusements of the settlers; is a bold rider at races; and enjoys himself at regattas, anniversary fetes and merry-makings, with some of the cheerful vivacity and good humour which delight us in the French'.67 Jingoism aside, this represented shared participation, and a willingness by Maori to embrace new sporting activities. However, Maori 
participation could sometimes extend beyond simply their sporting contribution and mutate into a novelty contribution, as one lurid account of Maori involvement in the 1850 Auckland Regatta indicates: 'These painted, feather-decked, half-naked gondoliers, giving free and unfettered vent to their desires, exhibiting animal passion in all their might and majesty of manly exertion, contributed largely to the success....Seven canoes, long snake-like vessels, fugle men with extravagant gestures, animating the pullers, tearing the water with their paddles...'.68

All the time, the European influence over sporting activities in the colonies was becoming increasingly dominant. A 1912 report produced by the Sydney Medical School suggested that 'The spirit of sport has always been inherent in the people of Great Britain and Ireland, and as many of the early settlers proceeded directly from the Motherland, it was only reasonable that they would take their sport-loving tendencies with them'.69 Part of the attraction of sport in agricultural societies (such as New Zealand in the nineteenth century) was that it helped to break the monotony of life, and promoted contact between communities that otherwise might remain apart. 70

The 1998 Maori Taskforce on Sport, Fitness, and Leisure noted that under Article the Second of the Treaty of Waitangi, Maori have '...self-determination/control in respect of their lands, villages and all that they value', and that in this context, 'Sport, fitness and leisure are activities that Maori have always considered a taonga'. ${ }^{71}$ The historical dimension of Maori sports involvement and its cultural role in Maori society is certainly significant. In rugby, for example, the 'Native' Team, assembled in 1888, toured New Zealand, Australia and Britain, playing 108 matches in total. During their match against Surry on 3 October 1888, the Haka was used for the first time by a sports team. ${ }^{72}$ Although the Maori team was largely a novelty for British audiences, Maori had been involved in rugby in New Zealand since at least the 
1860s. Moreover, rugby was seen by some of the settler community as an ideal sport for Maori, beginning a stereotypical portrayal of Maori involvement in sports that remains, in a modified form, today. An 1882 report in the Canterbury Times reflects the European perspective of the supposed suitability of rugby for Maori: 'At present this splendid game is the only one in which the youth of our savage breed can give vent to their fighting propensities. Barring the absence of lethal weapons, every scrimmage is a hand-to-hand fight with all the excitement of battle and none of the bloodshed. Young fellows are trained to run swiftly, to charge with bravery, to bear pain silently, and to stand cold and wet and other experiences common in warfare, with stoicism'.73 Similarly, Best made the connection between involvement by Maori in rugby, and a supposed legacy of Maori warfare: 'Ropata of Waiapu used to address the young men of the local football team in a stirring manner, recalling he deeds of their ancestors in more strenuous contests' ${ }^{74}$

By the end of the nineteenth century, there were several characteristics of participation in sport by the population as a whole that were becoming more evident in New Zealand. First, organised sporting and active leisure activity - assisted by Government- and council-supplied facilities such as parks and fields - reflected a belief that there were specific social benefits, including particularly social cohesion, to be derived from such activity. ${ }^{75}$ Second, most of the sports played in public were male-only. Third, sports were a means of defrocking the emerging class system (and to a lesser extent reducing racial distinctions), and of allowing a temporary egalitarianism to prevail.

Into the twentieth century, Maori sports, while incorporating European codes, were still predominantly marae-based, producing a unique cultural fusion: 'Haka, poi and action songs shared the billing with such sports as hockey, netball or tennis keenly contested at iwi gatherings that attracted thousands. The physical and leisure activities 
became a feature in settings such as those of Waihirere and Ngati Poneke'.76 This was a period of adjustment, in which pre-European cultural pursuits were accompanied by introduced sporting activities, but with the marae being the principal venue for both.

Embedded within New Zealand's embryonic international sporting activity was, however, a growing political and cultural component. Phillips describes the 1905 New Zealand rugby tour of Great Britain in terms of conquest and identitydefinition: 'The All Blacks represented, in the words of the manager Mr Dixon, 'the manhood and virility of the colony'. They were the Empire's finest sons...their success was thick with political implications. It gave a purpose and meaning to the colony itself'.77 This was a way for a recently-formed colony to demonstrate its independent cultural and political 'prowess'.78

However, Best witnessed a decline in Maori involvement in sports by the 1920s: 'Young native folk do not now indulge in games to any great extent. They have abandoned nearly all their old time games and have adopted but few of ours'.79 Sutton-Smith saw this as part of the process of acculturation, in which old sports were replaced with new, imported ones. By 1951, he noted that there were few surviving Maori sports and pastimes that '...did not have their counterpart in the European tradition'. 80

The cultural component of Maori sport has been revived in recent decades, with events such as waka racing, and taiaha and kapa haka competitions taking place, and once again frequently using marae as the base for these activities. This represents an interesting fusion. The activities and sports themselves are undeniably and identifiably Maori. However, the highly structured and rule-dependent nature suggests an external influence. This is a case of an indigenous sporting practice being oriented, modelled and conducted in accordance with the types of rules and regulations determined by a foreign nucleus. ${ }^{81}$ 
The literature suggests that sport and leisure activities are not simply an appendage to Maori culture, but that they are a valid component of it. This applies to non-Maori in the country as well. Michael King acknowledged this dual-track importance in an interview with Terry Locke. In reference to the cultural role of sport, King emphasised that '...it's central both in mainstream culture and Maori culture. Sport is one of those things that provides two ingredients that are very important to culture: the sense of distraction and entertainment - that level is very high; and the ability to do something with people who are like you and to do it as a team with a degree of communal cooperation. It's of interest that rugby was introduced into New Zealand by English immigrants, but that Maori took to it with relish and were so good at it, because there are elements in Maori culture that fit perfectly the kinds of qualities you need to be successful in a rugby or a rugby league team'.82 Ironically, in describing the relationship between sport and culture, King - perhaps unwittingly - perpetuated stereotypes about Maori and sport detailed in section 4.5 of this review.

\section{Establishing Links Between Sport and Culture}

While the historical aspect of the connections between sport and Maori culture serve as a foundation for understanding the links between the creation and maintenance of sustainable cultural infrastructures, and the contribution to an enhanced sense and practice of cultural identity, there are a range of other considerations that require examination to contextualise and define the links between sport and culture more generally. Strutt, for example, as early as 1801 observed that 'In order to form a just estimation of the character of our particular people, it is absolutely necessary to investigate the Sports and Pastimes most generally prevalent among them. War, policy, and other contingent circumstances may effectively place men at different times, in different points of view; but, when we 
follow them into their retirements where no disguise is necessary, we are most likely to see them in their true state, and may best judge their natural dispositions'.83 This general connection between sports and culture surfaced elsewhere in the twentieth century. When considering cultural life in the Soviet Union in the 1960 s, Morton was drawn to the fact that a survey of the sporting interests and commitment of a nation '...reveals the stuff of its social fabric and social system, and tells us much about other facts of political and economic life'.84 Around the same time, similar conclusions were reached by Cozens and Stumpf on American sport: 'Sports and games provide a touchstone for understanding how people live, work, and think, and may also serve as a barometer of a nation's progress in civilization'.85 The 1864 British Royal Commission on Public Schools identified the role of sports as helping to '...form some of the most valuable social qualities and manly virtues'. ${ }^{86}$

More recently, New Zealand culture - in the generic sense of the term - has become increasingly identified with sporting achievements. Most New Zealanders, according to Massey University research, derive greater satisfaction from international sporting performances than parallel achievements by artists, scientists, or business. 87 The invasive nature of sport on cultural identity, however, means that the association between the two is far more intricate. At a superficial level, Volkerling cites a tendency within the sporting sector '...to conceive of sport almost exclusively as physical activity of an exemplary sort', whereas there are accompanying 'essentialist notions' which present sport as being '...imbued with its own philosophy', and warranting '...a unique status by virtue of its efficacy in developing such valued social attributes as excellence, modesty, determination, integrity and sportsmanship'. ${ }^{8}$ Taken one stage further, sport has the capacity to develop what Baxter calls the 'normal human equipment' of individuals' cultural thinking 89 by '...championing concepts of cultural value based on...the 
grosser achievements of the body', ${ }^{90}$ rather than on the productivity of the mind or spirit.91 This represents a departure, or at the very least, a substantial redefinition of the commonly accepted meaning of culture. Volkering quotes Francis Bacon's definition of culture as '...the cultivation and manurance of men's minds', 92 and refers to Arnold's definition of the term as '...the best of what has been thought and said'.93 However, sporting activity allows the notion of culture to be expanded (or at least redirected). Kroeber and Kluckhohn broaden the definition of culture to mean '...the abstracted, intercorrelated customs of a social group', ${ }^{94}$ which has the primary function of creating and sharing meaning among the group claiming allegiance to that culture. ${ }^{95}$ Swidler nudges the definition of sport and culture closer together by describing the former as encompassing '...symbolic vehicles of meaning, including beliefs, ritual practices, art forms, and ceremonies, as well as informal cultural practices... and rituals of daily life'.96 Finally, Tenbruch advocates the pre-eminence of what he labels as 'representative' culture ${ }^{97}$ - one which is the sum total of the activities conducted by the prevalent or dominant lifestyle.98 It is constituted of '.. those beliefs, understandings, images, ideas, ideologies etc which influence social actions, either because they are being actively shared, or because they are being passively acknowledged as valid, right, good or the like'.99 Again, sports fits comfortably into this perception of culture.

Sport and leisure activities, in the current setting, serve a number of modified cultural functions. Various models have been developed to understand the motivation behind participation in sports. 100 The first of these is the 'humanistic' model, which portrays involvement in sports as an end in itself, reflecting a need by humans to participate in social activities. The second motivator is known as the 'therapeutic', model, in which the sport is a means to an end, the end being a form of control or of status elevation. Finally, there is the 'institutional' model, in which involvement in sports stems 
from cultural and/or social imperatives, and where commitment to the sport is driven not just by a personal desire for involvement, but also a need to satisfy the expectations of the group to which they belong. 101 This final model could be applied to some Maori engaged in sports, where obligations to the whanau may influence the extent, type, and duration of their participation. Dumazedier suggests that participation in sports is as much sociological as it is deriving from personal preference, and predicts that as cultural or religious ties weaken, then so too will the participation of members of the group in what are seen as traditional sports or leisure activities. 102

Snyder and Spreitzer even go as far as to suggest that sport can serve as an alternative for religion, offering a predominantly secular culture '...the capacity for genuine revelry and joyous celebration', 103 that was once delivered by religious festivals. ${ }^{104}$ In developing this idea, Real believes that 'The cycle of games and seasons...provides crucial 'sacred' markers breaking the 'profane' monopoly of secular time and space in our advanced industrial, technological society'. ${ }^{105}$ The implication for this review here is that if sport can become a substitute for both religious experience and religious practice, it can also potentially become just as much of a substitute for cultural practice and experience.

On a more practical level, one of the chief motivators of involvement in sports in modern industrialised societies has been identified by Murphy as the availability of time. The distinct organisation and compartmentalisation of time, coupled with the social urge to derive satisfaction from spare time, prompts engagement in sports activities. ${ }^{106}$ In a similar vein, Nash argues that the availability of clearly-defined leisure time creates an expectation among members of the society that this time ought to be utilised, and suggests that a hierarchy of utilisation exists with active participation at the top, as the most desired form of leisure-time utilisation. ${ }^{107}$ 
In addition to the various motivators for participation in sports is a body literature which addresses the measurement of this participation in terms of satisfaction. The ingredients which go into the satisfaction individuals derive from involvement in sports include perceived competence, motivation through social interaction, and the perceived freedom whereby a person does not participate because of compulsion, but because of personal choice. 108 A significant feature of the satisfaction that many people find in sport is the 'casual' element of involvement. Samdahl's research reveals that for many people, casual, impromptu sports activities '...just occur', rather than conforming to a highly organised format, ${ }^{109}$ and that it is this casual nature that attracts some people to sports.

Another branch of satisfaction gained from participation in sports is associated with social acceptance. Hutchinson, for example, notes that sport is '...a worthwhile, socially acceptable leisure experience that provides immediate and inherent satisfaction to the individual who voluntarily participates in an activity'. 110 Driver and Peterson expand on this idea, and suggest that social acceptance is a value which is seen as desirable by people who are inclined to participate in sport.111 Embraced within the framework of social acceptance are what are seen as derivative values, including risk, challenge, physical development, aesthetic appreciation, and spiritual renewal. What makes these values so important, Driver and Peterson argue, is that they can eventually lead to behavioural change, and can be transposed to non-sporting environments. ${ }^{112}$

This evidence strongly suggests that a distinct link is present between sport and society, and through this, the society's culture. However, in addition to the more general connections between sport and culture is another dimension that warrants consideration at this juncture, and that is the intergenerational aspect of sport and leisure activities. Several studies point to a desire by older persons to have some 
interaction with younger people involved in sports and leisure pursuits. ${ }^{113}$ Indeed, cultures run a possible future risk of '...severe problems...' if intergeneration relations are not maintained. ${ }^{114}$ Various authors have observed that there are intergenerational benefits which extend from involvement in recreational activities, including the transfer of knowledge between generations, enhanced community feelings, and an enhanced sense of worth for people of all ages. ${ }^{115}$

One of the significant links between sport and cultural expression is that both possess ritualistic elements. Leitner and Leitner note that both sport and culture require a regular routine of activities, 116 and thus set patterns of behaviour which both affect and define the self-perception of individuals, and to some extent the perception of their culture. Repetition and routine encourage familiarity with the culture, and sport is an especially strong vehicle to assist with this because of its heavy interactional component. Looking at this relationship from an alternative angle, though, the routines of culture can serve as a barrier to participation in sports. In urban settings in various parts of the world, for example, sedentary lifestyles, insufficient transport, and long working hours can encroach on the capacity of some people to participate. ${ }^{117}$

As urban life (and to a considerable degree rural life as well) in modern countries such as New Zealand evolves as a result of technological and structural changes, the availability and use of time similarly develops. Levy and Kubey have assessed these emerging patterns with reference to participation in sports and leisure activities, and concluded that the rise of permanent part-time work, the demise of traditional work-free weekends, the requirement for ongoing education and training long after the conclusion of formal fulltime study, and the burden of child care, affect the capacity of groups or teams to be assembled.118

Sport is also increasingly part of the process of defining cultural experience for individuals and groups. The individual or group identity can be largely determined through narratives 
which '...link together the interrelated significance of time, place and social interaction'. 119 Blake draws attention to this capacity of sport to become a cultural experience for people, noting that it '...can help to organise the narrative of time, place and identity. The memories of participation or spectatorship; the certificates and trophies of the youthful athlete, proudly displayed in the middle-aged lawyer's study; the cards from a lifetime's attendance at race meetings; songs and movements associated with victories and defeats; all can place people in their own time and space'.120 In a similar fashion, sports can serve as '...vehicles of identity, providing people with a sense of difference and a way of classifying themselves and others'. ${ }^{121}$ Volkerling concludes that sport represents a cultural resource for the formation of identity: 'An essential function of culture is to instil values which guide our actions and judgements in different situations. In this respect, a large range of human behaviours may be reinforced through exemplary performances on the sporting field'. ${ }^{122} \mathrm{He}$ then cites Simon's research on the role of sport in the cultural transmission of standards of '....appropriate conduct'. ${ }^{123}$

There is an almost contradictory element in this relationship between sport and culture however. Because sports offer the possibility of individual development within a codified structure that is, at least in some respects, outside traditional cultural parameters, sport can serve as a de facto cultural experience. The process of challenge and accomplish can serve to reinforce this adherence to sport as an individual cultural influence. ${ }^{124}$ Such experiences '...induce people to transcend their genetic and cultural conditioning to seek out experiences that 'go beyond established patterns of behaviour'. To this extent...[such] experiences...[extend] the scope of social and cultural possibility'. ${ }^{125}$ 


\section{International Initiatives in Indigenous Participation in Sports}

The intersection of culture and sport is accentuated in places such as South Africa, where cultural identity in an essentially bi-cultural society damaged by decades of apartheid is a pronounced national issue. In such a setting, Mtsweni has observed that sport serves a role '...for social cohesion, nationbuilding, human development and for the liberation of the human spirit', whereas previously, there had been efforts by '...the apartheid state to use culture and sport as weapons of division, denigration and exclusion'. ${ }^{126}$ The role of sport in the reconstruction of South African society was considered sufficiently important that the South African Government's 1994 Reconstruction and Development Programme for the country declared '...that Sport and Recreation are an integral part of constructing and developing a healthier society'. ${ }^{127}$ In March 2005, South Africa held its annual Indigenous Games, which President Thabo Mbeki had been instrumental in organising because of the opportunity it afforded to optimise '...South Africa's cultural heritage and values thereby instilling a sense of pride in our cultur[e]'. ${ }^{128}$ It enabled, in the words of the organiser, Joe Phaahla, a '...celebration of our indigenous culture through sport'. ${ }^{129}$

In Australia, a similar approach to cultural development was attempted with the introduction of hockey in parts of rural Queensland. The Remote and Indigenous Communities Hockey Program was complemented by a unique 'Hockey Art' initiative to promote links between the sport and Indigenous culture. Traditional indigenous designs were painted onto hockey sticks as a means of fostering greater participation in sports among indigenous communities, and '...promoting positive lifestyles [among Aboriginal communities]...and providing new avenues for self-development'. ${ }^{130}$

As in South Africa, the indigenous peoples of North America operate their own sporting tournament, in this case, one held annually (in various forms) since 1967. The mission 
statement of the North American Indigenous Games is 'To improve the quality of life for Indigenous peoples by supporting self-determined sports and cultural activities which encourage equal access to participation in the social/cultural fabric of the community they reside in and which respects Indigenous distinctiveness'. ${ }^{131}$ In addition to more conventional emphases in sport, the North American Indigenous Games organisers stress the '...holistic development of the athlete, which is essential for balance and harmony....[and] the need to cultivate the mental, physical, emotional and spiritual aspects for the athlete's well being and complete development'. ${ }^{132}$

The fact of cultural cohesion, brought about through involvement in sports, is a substantial element in the emergence of specifically indigenous sporting activities. In 1995, a Te Puni Kokiri publication, 'Omangia To Oma Roa: Maori Participation in Physical Leisure', noted, for example, that 'The primary motivation for sedentary Maori women to join the walking programme was their keenness to be involved in and enjoy the company of other Maori women....Maori respond positively to Maori initiatives through a sense of ownership of the concept and process [of the activity]'. ${ }^{133}$ This represents a further stage in the entwining of sporting activity with cultural identity and cultural expression. These sorts of interactions produce a situation whereby sport becomes a vehicle to enhance cultural expression. Ironically, though, sport also has the potential to become a means - maybe even the principal means - of cultural expression - thus altering the complexion of the culture in the process.

\section{The Relationship Between Sport, Culture, and Location}

Another aspect of the nexus of sport and culture involves the role of location and physical space. Hemming and Rigney have argued that the act of simply playing sport on a piece of land involves the '...ongoing colonisation of Indigenous space, both 
physically, and through the production of powerful sporting narratives'. ${ }^{134}$ These narratives, it is suggested, involve the reconstruction of indigenous culture to comply with modern, Westernised expectations of the culture.135 Moreover, Nauright has noted that the venues of sporting activity have become '...sites for the generation of identities for local, regional and national consumption'.136 The consequence of the reconstruction of cultural representation through sports has resulted in narratives being produced which '...exclude Indigenous knowledges and most importantly marginalise the histories of invasion, dispossession and oppression that have emerged comparatively recently in...national histories'. ${ }^{137}$

Hemming and Rigney extend this argument by suggesting that sporting sites produce a range of cultural meanings, but are usually dominated by the meaning which reflects the current power relationships in the society. This process comes with a warning: 'Sometimes the dominant meanings produced at a site can oppress particular groups. This is often the case in a settler-nation...where dominant institutions such as sport continue to be colonising and colonial in character'. ${ }^{138}$ The questions that emerge from this segment of the literature relate to the extent indigenous culture, history and contemporary realities are recognised, the presence, absence, or misappropriation of indigenous art or symbols, and the potential for cultural destabilisation or modification as a result of the specific manner by which sporting events can reconstitute cultures. ${ }^{139}$

Jarvie and Sage have pointed out that sport is an industry, a set of social, cultural and economic relations, and a site for the exercise of different kinds of power relations. Therefore, exploring sport means asking questions about the nature, practice and organisation of sport and its relationship to power. ${ }^{140}$ Thus, while sport can be an instrument of 'cultural suppression and cultural hegemony on the one hand', it can paradoxically serve, as Birrell has highlighted, as a force for '...cultural regeneration and cultural survival on the other'. ${ }^{141}$ 
Bhabha's 1996 seminal work on cultural space drew attention to issues such as these, by elevating the significance of cultural sites from the domain of archaeology, ${ }^{142}$ to what he identified as a 'third space', in which cultural expression can occur through physical representations. ${ }^{143}$ Taken to its conclusion, the misappropriation of the representation of space has the potential, as Swanbury Penglase predicts, to '...create significant barriers to investigations of historical and continuing colonial relations'. ${ }^{144}$ An extension of the roles of sport, location, and culture appears in the work of Brown and Taylor, in which the introduction of organised sports to British colonies in the nineteenth century effected a lasting change in cultural perceptions. Even today, they suggest, sport '...remains a symbol of British colonial culture. It stands for progress, civilization and the systematisation of sports and the importance of the rule of law'. ${ }^{145}$ The implication of this notion is that there can be no viable cultural expression of sport outside these parameters, and that what cultural sport activities do occur must comply with the introduced cultural norms.

Nauright draws attention to the homogenisation and sanitation of cultural identities through sporting cultures, which necessarily rely on the universalisation of history, in which potentially shameful moments are suppressed and in '...the rush to demonstrate 'newness' and harmony, history disappears leaving us with little more than a 'white's own' voyeuristic view of 'native' culture'. ${ }^{146}$ As a consequence of this, Hemming and Rigney raise the possibility that sport can end up creating an environment in which there is a '...total absence of indigenous voices, images, and understandings, coupled with the pervasive 'normalising' discourse of... [the sport], makes ...[the sporting location] what could perhaps be termed a hyper-colonial site'. ${ }^{147}$ 
The location of sports is therefore an important consideration in the relationship between sport and culture. Sporting narratives, heritage narratives, and cultural narratives are brought together at the venue of a sporting activity, possibly, at times, at the expense of the political and social realities of the participants in those sports. ${ }^{148}$ The ultimate result is the manufacturing of a '...global white culture of sport...' that is '...totalizing ... through its notions of apoliticality'. ${ }^{149}$ According to this approach, in such a setting, all cultures that participate in sports are deemed to be supportive of this '...global white culture' simply by virtue of the fact of their participation. ${ }^{150}$ The internationalisation of sports through the media, according to Baudrillard, only accentuates this phenomenon. 151

For indigenous people involved in sports, the matter is made more complex by the suggestion that they may have multiple perspectives on a single place. These could be social, cultural, political, historical, aspirational, and even imagined. What leads to the complexity is that these perspectives are not mutually exclusive, and therefore may coexist. As Keith and Pile note, '...one does not merely cover the other; one is not more real than the other'. ${ }^{152}$ As far as the approach of Hemming and Rigney is concerned, the Europeanisation of sporting activity '.. does not mean that non-Indigenous experiences are meaningless [but] rather it means that we should not rely upon non-indigenous experiences and ideas as the only truth'.153 Maguire, however, provides a note of restraint when looking at the extent of the Europeanisation of sport and sport culture: 'It is possible, however, to overstate the extent to which the West has triumphed in terms of global sports structures, organisations, ideologies and performances. Non-Western cultures, as noted, resist and reinterpret Western sports and maintain, foster and promote, on a global scale, their own indigenous recreational pursuits (eg., Kabbadi). Clearly, the speed, scale and volume of sports development is interwoven with the broader global flows of 
people, technology, finance, images and ideologies that are controlled by the West, and by Western men. In the longer term, however, it is possible to detect signs that the disjunctures, and non-isomorphic patterns, that characterise global processes are also leading to the diminution of Western power in a variety of contexts. Sport may be no exception'. ${ }^{154}$ The conclusion to be drawn from these varying perspectives is that a dynamic exists between the various cultural, sporting, and business forces in the sports realm, and that as yet, the tension inherent in this dynamic remains unresolved.

\section{Sport and Cultural Stereotypes}

One aspect of sport and culture that is probably more popularly misrepresented than most others is that of racial stereotyping. Godwell has observed that indigenous peoples in the South Pacific are portrayed in '...racial stereotypes of physicality, self-confidence in skill acquisition and practice, improved performance, belief reinforcement and, finally, reaffirming [indigenous]...identity formation'.155 Hence, for each example, sports people belonging to certain ethnic groups are described as being 'natural athletes', 156

One interesting feature of racial and cultural stereotyping is that it serves two distinct audiences. The first is the mass audience, which in New Zealand's case is predominantly nonMaori. The second is the group actually being stereotyped. In both instances, it superimposes understandings and expectations of the cultural group being stereotyped, and how the observer audience ought to react (and maybe even instinctively encourage) those traits in the cultural group. ${ }^{157}$ This has reached such an extent in the United States that Lapchick claims that '...whites tend to "think black" when they think about the major sports', 158 and while the focus of the stereotype is non-white, information about this sub-group is '...being written about by a mostly white male media for a preponderance of white fans'. 159 When it comes to the 
portrayal of sports on an ethnic basis, statistics from the United States reveal how, in that country, the representation of the sub-group is controlled by the dominant culture: "There are 1,600 daily newspapers in America. There are only four African American sports editors in a city where there are pro franchises and 19 African American columnists. Both numbers, as reported at the recent conference of the National Association of Black Journalists, have almost doubled since 1998 and represent a positive sign. Nonetheless, there are no African American sports writers on 90 percent of the 1,600 papers'. 160

Edwards has taken the portrayal of ethnic minorities, specifically non-white groups, to its worrying conclusion, arguing that in media portrayals of this group, '...what really is being said in a kind of underhanded way is that blacks are closer to beasts and animals in terms of their genetic and physical and anatomical make up than they are to the rest of humanity. And that's where the indignity comes in'.161 Such is the persuasiveness of this approach to cultural and ethnic representation that, as Entine as demonstrated, '...even successful blacks have come to recite a racist party line', with respect to their own participation in sports. ${ }^{162}$ The reason for the success of such simplistic stereotypes is because there is a often a corresponding mantra about the opportunities sports afford for what are euphemistically and inaccurately referred to as underprivileged people. In the experience of blacks in the United States, sport becomes a subculture in which they '...can assert themselves and enjoy success to a degree that makes the world of sport look like an interracial utopia. Compared to other venues of competition and endeavour, such as business, science or the law, the sports world is, in fact, an extraordinary social phenomenon that seems to contradict some familiar racial stereotypes. The sheer celebrity of the black athletic star seems a refutation of the colonial anonymity of the black masses, his wealth contrasts with traditional images of black poverty, while his honored status 
appears to dissolve centuries of racial subordination'. ${ }^{163}$ But, as Hoberman points out, much of the 'success' of ethnic integration in sports masks the realities of the socio-economic position of the group as a whole: The upward mobility and wealth achieved by the most successful black athletes dominates media coverage and promotes an illusory sense of social advancement for blacks as group. Who would guess, in a world of NBA millionaires, that the net worth of the average African-American home is only one-tenth that of its white counterpart?'164 According to Hoberman, the consequence of the manufacturing of a distinct racial image in sport has been that '...stereotypes of black athletic superiority are now firmly established as the most recent version of a racial folklore that has spread across the face of the earth over the past two centuries. At the same time a corresponding belief in white athletic inferiority pervades popular thinking about racial differences. Such ideas probably do more than anything else in our public lives to encourage the idea that blacks and whites are biologically different in meaningful ways'. ${ }^{165}$ Conservative racial thinkers such as Murray and D'Souza have claimed that black athletic superiority is evidence of more profound racial differences 166 - something which the representation of ethnic groups in sports seems to confirm, at least at a superficial level. ${ }^{167}$

In recent decades, the media has played a growing role both in the creation and perpetuation of cultural stereotypes. The media is necessarily a tool and disseminator of mass culture, 168 and it is particularly effective when simplifying or reducing minority cultures to forms that can be accommodated and broadcast in images suitable to the dominant culture. The major driving force behind the type of culture portrayed in the media - particularly in television - is advertising revenue. Sporting culture especially is blended with commercial imperatives, '...fusing together within a single organisation the roles of major sponsor, chief initiator and manufacturer of events'. 169 
One minor but indicative consequence of the media-based commercialisation of sport is has been '...the development of a transnational sporting labour market in which remuneration rather than national or local loyalties becomes the primary motivation of sports professionals'. ${ }^{170}$ This is almost the antithesis of culture - national and cultural loyalties are initially dissolved and then re-fabricated in order to create the possibility for the viewer of affiliation or identification with sports teams. The experience of the English soccer club Chelsea in 2005 demonstrates the extent of this phenomenon. Although ostensibly an English team, competing in an English soccer league, not one member of the team was actually English. Whitson explores the removal of cultural, regional, and national affiliation from the professional sporting world, and points to the media - and television in particular - as the instrument that has facilitated this process: '...the most farreaching consequence of television...has been the gradual 'delocalisation' of sporting tastes and loyalties....Television...encourage[s] and normalise[s] the practice of fans identifying with teams based elsewhere, in contrast to older loyalties based on geography'. ${ }^{171}$ At the same time, the sport media can reproduce ideologies of cultural dominance. ${ }^{172}$ Rowe claims that this dominance is simply a component of the matrix of broader cultural dominance: '...sports discourse cannot be avoided, even by those most determined to do so. For what "serious" political or economic story is complete without resort to the language of "team players" and "level playing fields"?'173 A process accompanying the mass media projection of sport is the trend towards greater viewing and reduced direct participation: ${ }^{174}$ '...for many people sport is not something they either play or directly experience first-hand; rather, they are involved in a mediated experience in varying degrees of passionate commitment to socially constructed media sport as members of media audiences'. ${ }^{175}$

Sport can still serve cultural functions, and the process of globalisation may not affect this capacity to deliver to certain 
cultural expectations. However, it does have the consequence of separating culture from a specific sense of location, causing the final cultural 'product' to be far more fluid. Because this geography-free cultural construct mirrors smaller-scale, location-specific sorting events, television spectators are able to exercise '...the cultural connoisseurship of the popular audience'.176 Volkering draws attention to the explicit transmission of cultural and ideological messages through televised sports: 'In terms of domestic politics...the celebration by governments of sporting excellence and achievement has been equated with strategies designed to foster a political culture sympathetic to the assumptions of methodological individualism that underpin the ideology of the New Right....In terms of international politics it is suggested that the televised interpretation of sports spectaculars concurrently constructs (or reconstructs) and ideological framework for communicating the national character of the other countries'. ${ }^{177}$ The resulting '...elaborate cultural game...' 178 requires cultural groups to be reduced to basic, and allegedly innocuous stereotypes.

These stereotypes, however, are often far from innocuous. While their outward manifestation may appear inoffensive, sport has the potential to represent a tool of hegemonic control'. ${ }^{179}$ Cashmore describes a process whereby 'ruling groups' have a vested interest in sport because of the capacity sport has '...in drawing subordinate groups toward an acceptance of ideas that are fundamental to their control'. This is said to apply particularly in colonial settings: '...by participating in sports, populations who came under...British influences were taught teamwork, the value of obeying authority, courage in the face of adversity, loyalty to fellow team members (especially the captain) and, perhaps most importantly, respect for the rules'. ${ }^{180}$ In New Zealand, elite secondary schools are said to be part of this process of using sport to magnify cultural power. ${ }^{181}$ The fact that the stereotype may not appear harmful to the subject does not alter its potential to misrepresent and re-shape cultural 
perceptions among all affected by the stereotype. Neither does it assist in any genuine effort to nurture cultural well-being among the stereotyped group in particular.

\section{PRESENT IMPLICATIONS FOR MAORI CULTURAL IDENTITY AND WELL-BEING}

At present, there remains a paucity of literature that directly addresses how Maori cultural identity might be affected in the future as a consequence of involvement in sport. Much of the likely nature of the impact on Maori cultural identity will certainly be influenced, though, by broader developments taking place in the sporting industry, particularly the commodification of sport, the role of the media, and emerging perceptions about how sport features as an appendage or component of culture. The following sections review some of these issues.

\section{The Link Between Whanau Support and Maori Participation in Sport}

Thompson, Rewi, and Wrathall have observed that whanau support is a critical component both in encouraging participation in sports in the first place, and on maintaining that involvement.182 Based on their research with thirteen Maori athletes, they concluded that 'Most [Maori] athletes came to their sport by following parents or sisters, brothers, or other whanau around sports grounds. All identified as Maori and most felt that when they made teams they liked to have other Maori in tem as this gave them support'. ${ }^{183}$ In this setting, Maori cultural identity could be said to have been enhanced as a consequence of whanau support leading to participation in sport. However, this enhancement of cultural identity is qualified by the fact that it was dependent, in some instances, on there already being a critical mass of Maori involved in the sport. 
The element of pride in sport is another feature that has a bearing on Maori self-identity through involvement in sport. In 1996, the New Zealand Sports Foundation identified one of the roles of sport as bringing pride to the individuals directly involved, and through them, to their communities. ${ }^{184}$ McConnell and Edwards point out that this pride reaches down to increased levels of social acceptance for sports participants, and the sense of confirmation of a person's identity simply by virtue of the fact of participating in sports. ${ }^{185}$ This is so significant, argues Coakley, because identity is the basis for self-direction and self-control in people's lives. 186 McConnell and Edwards note that in New Zealand, a considerable portion of self-identity for many individuals is obtained through sports: 'Our early experiences may well influence our attitude toward, for example, team participation, being a team member, contributing to a group effort, accepting defeat or victory, and experiencing intrinsic or extrinsic reinforcement of he pleasures or despair of sporting experience', 187 - all potentially useful traits for whanau membership and the enhancement of Maori identity within a whanau setting. MacClancy states that in such settings, sports are '...vehicles of identity, providing people with a sense of difference and a way of classifying themselves and others, whether latitudinally or hierarchically....sport may not be just a marker for one's already established social identity, but a means by which to create a new social identity for oneself as well'. 188

There is a risk, however, that the cultural well-being of Maori participants in sports may be undermined by equally powerful forces that come to light in sporting activities, such as '...over conformity, unquestioning conservatism, and acceptance of deviant values (e.g. cheating, violence) [which] are the result of an over-identification with sport and certain [negative] values that may be encountered'.189 Even if such obvious deviance is not evident, the need to avoid embracing artificial cultural constructs - as MacClancy implies 190 - is 
vital if cultural well-being is to be enhanced through the sporting experience.

\section{Cultural Collision}

Even though the sense of 'being Maori' could be enhanced for some Maori by becoming involved in sports where there is already a sufficiently high frequency of Maori participation, 191 there is a corresponding indication in the research of Thompson, Rewi, and Wrathall that in sports dominated by non-Maori - especially at an administrative level - there is a lack of knowledge by non-Maori on how to interact with Maori.192 This manifests itself in four principal ways. Firstly, there is evidence of cultural insensitivity and intolerance. This is experienced by all respondents in the research, and ranges from a simple lack of understanding of Maori cultural nuances, right through to fully-blown racism. Token gestures are sometimes made, but these are often based on stereotypes, such as the anticipation that Maori would organise the group to sing at after-match functions. ${ }^{193}$

Secondly, communication and the use of language tends, in some cases, to favour the administrators' ways of thinking. Cultural presumptions about not questioning kaumatua are not generally taken into consideration by non-Maori administrators, and 'pakeha jargon' is used in many cases which excludes Maori from discussion.

Thirdly, there is a lack of information for some Maori who are involved in administration or in seeking funding. Part of this can be attributed to having a lack of networks in the hierarchies of funding agencies. Some express the feeling that it is 'like a closed shop'. Neither is there a feeling of iwi ownership of the processes involved in obtaining funding for sports. To this extent, there is a sense of isolation from the sources and controllers of sports information. 194

Finally, there is evidence of manipulation and exploitation. Thompson, Rewi, and Wrathall discovered that 'Feelings of 
being manipulated occurred in many areas of the athletes' careers, from the selection criteria to veiled threats of being dropped from the team, to being asked to organise team songs and after-match presentations'. ${ }^{195}$ The cumulative effect of this manipulation and exploitation was that the sportspeople concerned '...felt isolated from friends, whanau and other team-mates'. ${ }^{196}$

The implications of this research suggest that there is a requirement for more Maori involvement in the higher levels of administration in sports, a greater need for education on cultural differences, and increased levels of participation by Maori in sport, to the point where a critical mass is reached, and where there is consequently a safe cultural space for Maori in those sports.

\section{Racial Stacking}

Whanau experiences could be enhanced by a sufficient concentration of Maori in a sports team or in sports administration. However, Coakley has observed that this can sometimes become a self-perpetuating process leading to what has been identified as 'racial stacking'. ${ }^{197}$ This describes a process '...in which players from specific racial or ethnic groups are either over- or under-represented in certain positions in sports teams'. ${ }^{198}$ This perception, which has already been prefigured in section four of this review, is portrayed by Coakley as an over-simplified form of social Darwinism, which assumes that '...white-skinned people have intellectual superiority and dark-sinned people have more 'savage-like', instinctual physical capabilities'. 199 Certainly, based on current media portrayals, this tendency is reflected in the coverage given to sports in New Zealand, and especially, the involvement of Maori and Pacific Island groups in certain sports in particular. Racial stacking has been a feature of sports in many countries, 200 and New Zealand seems to be no exception to it. 201 
This is one of the dilemmas of Maori involvement in sport. If there are too few in a particular team, then there could be feelings of cultural isolation and exposure. However, on the other hand, if there is a higher concentration of Maori in a team, then it could reinforce the sorts of stereotypes about Maori sporting capabilities which are equally harmful in the long term. Cultural identity could therefore just as easily be damaged as enhanced, especially if the appropriate mechanisms for the support and protection of that identity are absent.

\section{The Treaty of Waitangi and Maori Involvement in Sport}

The Treaty of Waitangi (1840) was concluded when Maori were still the dominant culture in the country. In the succeeding sixteen decades, it has become a part of the cultural identity of all New Zealanders, but specifically to many Maori communities whose ancestors gave their consent to the agreement. The Treaty undoubtedly has implications for Maori cultural identity into the future, and so it is useful, at this juncture, to consider its connection with Maori participation in sports. The Treaty is particularly pertinent to sport in the area of Government policies affecting sporting participation. The 1987 State Owned Enterprises Act confirmed that the Crown was not permitted to act in a manner that was inconsistent with the Treaty of Waitangi.202

However, although sport can be seen, on many levels, as a component of Maori culture, and even a taonga, as Biggs has implied, 203 there has been little recognition of this in existing literature relating to the Treaty, although as McConnell has suggested, 'It may be argued that sport in New Zealand, with its support from the government, is controlled by Pakeha and Pakeha concepts of sport, so that the partnership ingrained in the Treaty has not been realised'.204 McConnell then returns to territory covered by other analysts of sport culture in observing that sport '....in New Zealand, like all ideologies and 
constructions, has been ignored, defined, and reinterpreted through agencies of the majority culture',205 and in making this claim, accuses the bodies such as the Hillary Commission and the New Zealand Rugby Football Union as failing to '...equitably address understandings of Maori knowledge, belief, experience, and practice in sport. Despite the often expressed goodwill, rarely do they address such aspects as partnership, Maori as the official language, equity in coaching players with differing cultural orientations, Maori sports that are unrecognised by Pakeha, sport definitions, or the impact of the Treaty'.206 Even thought the Hillary Commission states that it has regard for '...promoting....indigenous and ethnic forms of sport, fitness, and leisure', and to '...encourage Maori to play sport at all levels and to seek opportunities for Maori as participants, leaders, coaches, and managers', and that the Commission strives to encourage '...national governing bodies to take the needs of Maori into account in developing their strategies and programmes', 207 this falls short of the threshold for actual partnership. It still represents one party to the Treaty effectively dictating the terms of participation (albeit apparently positive terms) to the other. In fact, the Hillary Commission comes in for criticism from McConnell for acting at variance with its policies and breaching its Treaty obligations: 'The Hillary Commission's condemnation of the NZRFU [New Zealand Rugby Football Union] for its 'flourishing' Maori structure illustrates the lack of awareness of equity held by national sport policy-makers, when it is realised that the rugby union board has one Maori member and the rest are Pakeha. Racism is about power-based domination'. ${ }^{208}$

McConnell concludes that because sport is '...not culturally neutral', there is a distinct issue of a lack of Maori cultural power in the country's sporting infrastructures, 209 and this contravenes the partnership, participation, and protection principles of the Treaty. Moreover, the fact of a group being either advantaged or disadvantaged through the manner in which an institution is organised can be the basis 
for institutional racism. ${ }^{210}$ Even if the intent of racism has been removed, the '...legacy of Maori bodies being subjected to Pakeha control and negation of the Maori body as a taonga', may persist. 211 McConnell's most important suggestion is that the physical bodies of Maori, just like te Reo Maori, is a taonga, and therefore, the involvement of this taonga in sport requires similar protection (statutory if necessary) to preserve this right under the Treaty. ${ }^{212}$

It is clear from these assessments that one way in which Maori cultural identity may be at the very least protected, and possibly even enhanced, is through greater recognition of the Treaty and its principles in the country's sporting institutions. This would require recognition of the physical bodies of Maori as taonga, and for the same Treaty rights to be afforded to Maori in sport as are afforded to other taonga, such as te Reo Maori. Such an approach would certainly both define and potentially enhance Maori cultural identity and well-being in the sporting milieu.

\section{NURTURING MAORI INVOLVEMENT IN SPORTS}

There are several means by which a people may be encouraged into greater participation in sporting activity. However, in the case of Maori involvement in sport, fostering this participation requires an acknowledgement of the previous data presented in this review serving as a strong caveat. A blanket drive to get Maori involved in sports would run the risk of creating or accentuating some of the problems highlighted in the preceding sections of this review. This section survey the literature based on the methods and purpose of encouraging involvement in sports, and some of the issues that arise in relation to the promotion of cultural well-being for Maori through participation in sports. 


\section{An Holistic Approach}

There is a convergence in the literature on encouraging people's greater participation in sports that the approach needs to be holistic, and incorporate a combination of strategies. Henshall lists ten factors that, in various combinations, would lead to greater popular involvement in sporting activities. These are: 'A National / State / Local / Household / Individual strategy which addresses the importance and essential value of physical activity as a core component of life activities. Not as an ancillary activity of life; recognition that sedentary behaviour can consume our lives unless proactive integrated measures are encouraged, promoted, resourced and provided through, business, education, family and leisure sectors in life; eating habits must be included as part of the solution; there must be a stronger degree of seriousness and resourcing of a physical activity strategies; strategy must be brought down to a personal household level, in order to control technology rather than letting technology control and restrict community involvement; urban planning and personal transport systems linking levels of personal commuter options such as cycleways, walking trails and scooter paths should be included; a work-based system which rewards business for encouraging physical activity programs; an education-based system, which introduces and links students to the myriad of physical activity opportunities rather than sport; the Development of many easily accessible / free opportunities in neighbourhoods; a leisure/health professional partnership driving a strategy which impacts on the majority of the population'.213 When it comes to applying these approaches to Maori, there is an extra layer of issues that require consideration. Sport Auckland has identified involvement with Maori communities as a key component in encouraging participation, and cites its relationships with various Maori health providers as a prerequisite in developing models for Maori involvement in physical activity generally, and sports in particular.214 
Karehana and Pitama have concluded that sedentary Maori are motivated to be physically active if participants in organised activities: '...can incorporate beneficial physical activity into their lifestyle [and] are involved with whanau and hapu in activities organised by Maori for Maori'.215

In 1995, Te Puni Kokiri set guidelines on physical activity participation for Maori. The guidelines identified a number of barriers to physical activity including transport, cost and whakama. ${ }^{216}$ These guidelines provided marae-based programmes around the country through a network of kaiwhakahaere (co-ordinators) based within Regional Sports Trusts. Te Puni Kokiri cites evidence of 'The philosophy of 'By Maori for Maori' organisations such as Te Hotu Manawa Maori [which] deliver a range of physical activity and nutrition programmes and training. A promising Hikoi walking programme has been run in partnership with Hutt Valley Health and local communities. An evaluation of this programme showed that sedentary Maori have become physically active and maintained activity levels for more than three months'.217

Another key element identified by the Ministry of Health in improving physical activity promotion in Maori communities is the provision of workplace training conducted by Maori: 'Maori provision of training in healthy lifestyle activities (physical activity, nutrition, healthy weight and Auahi Kore) is critical', concludes the Ministry's report.218 Furthermore, when it comes to implementing these training regimes and assessing their value, '...Maori and Maori values and beliefs must be included in needs assessments, development of strategic directions, prioritisation, planning, service delivery and monitoring and evaluation'. ${ }^{219}$ The Ministry has articulated a series of actions that district health boards can undertake to assist in the promotion of sports participation among Maori communities. These include: 'Work in partnership with Maori communities to support and develop programmes that are appropriate for local Maori and that are delivered by Maori 
where possible. These programmes should have a strong emphasis on involving the whole whanau in physical activity; purchase services that promote physical activity based in key settings in Maori communities, such as marae (both iwi-based and urban), kohanga reo, sports clubs; support a range of activities acceptable to Maori communities (eg, a mixture of team-based activities, hikoi as a group and individual activity, and traditional activities such as kapa haka, taiaha, waka ama, kaimoana); work through the Primary Health Care Strategy to encourage the expansion (and adaptation) of the Green Prescription Scheme for use by Maori primary care organisations (in partnership with SPARC/Ministry of Health); and Purchase and support 'by Maori for Maori' training of community workers in healthy lifestyles'.220 As with Henshall's suggested approach, a systematic combination of these elements is required in order to make such efforts effective.

\section{Cultural Isolation and Social Inclusion}

One of the effects of Maori cultural isolation - defined in this context as Maori living outside of New Zealand - is that the role of sports participation in nurturing cultural well-being becomes far more pronounced. Bergin has seen, for example, that 'Sport is an important aspect of cultural identity for New Zealand Maori migrants living in Australia. Maori sporting endeavours, especially at festivals such as the Taki Toa Tournament in New South Wales, often reveal distinctive Maori features of cultural performance, in the rituals prior to a game, in the spirited manner with which a game is played, and in the whanau (large/extended family) spirit of belonging and celebration that is encouraged after a game'.221

What is important about this behaviour is the possibility that, under the right circumstances and with the appropriate levels of support, it could be applied to Maori in New Zealand. The sense of cultural isolation within the country could be just 
as acute for some Maori, although the proximity to Maori cultural markers (such as ancestral land) may disguise this. Involvement in sports could be marketed as one of several ingredients for those Maori who wish to locate of re-affirm the cultural dimensions to their lives. Bergin notes that this need not lead to the 'ghettoisation' of Maori. In the case of participation in sports in Australia, he notes that 'Widespread Maori involvement in sport has provided an important avenue for Maori migrants to mix socially with Aboriginal and other Australians in their local communities, and to gain acceptance, respect and, in some cases, economic advancement'.222

Also in Australia, the Islamic Charity Projects Association was formed to serve a '...pioneering role in bringing Muslim youth together and instilling in them values and ideals that provide benefit not only to the Muslim community but also the broader Australian community'. ${ }^{223}$ Again, the opportunity was taken to use sports overtly as a device to deliver specified cultural outcomes. The creation of the Spears Soccer Club by the Islamic Charity Projects Association was not simply an exercise in extending the number of Islamic youth involved in soccer. In its documentation, the organisers of the soccer club noted: 'It is important to mention here that the Club's efforts were not limited to sports activities. In fact, included in the schedule were weekly classes of behavioural and moral guidance. These classes were addressed to children and teenagers. They focused on increasing their awareness to the importance of consistently displaying Islamic conduct and principles as well as teaching matters in the essentials of the Belief'.224 There are elements of social integration and cultural exclusivity in the club's statements: 'Spears Sports Club understands that the need to contribute to a harmonious environment starts with the productive involvement of our Youth with the wider Australian community. Accordingly, the Club members and players participate in neighbourly activities such as Clean-Up Australia, and children's festivals. This 
enhances the image of the Islamic youth, enriches their commitment to Australian society and provides inspiration to others in terms of their moderate Islamic direction'.225 This is a position that could suit Maori sports participants, in that it allows for social integration with other ethnic and cultural groups without undermining the cultural imperatives at the heart of Maori identity.

\section{International Approaches}

Various countries have promoted popular participation in sports, but usually for specific socio-cultural purposes. In Singapore, for example, the Government's encouragement of involvement in sports has aimed to achieve the dual goal to '...build a healthy population and use it as a means of generating racial harmony and nation building. ${ }^{226}$ With the Singaporean Government's efforts to promote sporting involvement generally as well as focussing on sporting excellence, Kirk concludes that '...we are likely to see more sponsorship money and government funds going to sports in the future. In fact, the government has already accepted the interim recommendations of COSS and, together with the Singapore Pools, the government will be committing an additional $\mathbf{S} \$ 500 \mathrm{~m}$ to sports over five years. These developments should lead to an increase in sports participation and a growing sports industry. Going by the experience of other countries, like the United States and England, such developments have usually led to a corresponding increase in issues concerning the regulation of sports and sports organisations. Singapore is likely to see a similar development'.227 The increasing role of the state in regulating sports participation may become an issue in future attempts to encourage Maori involvement in sports in New Zealand.

In India, the 2001 National Sports Policy summarised that Government's approach and rationale for assisting the 
population to become increasingly involved in sports: 'Activities relating to Sports and Physical Education are essential components of human resource development, helping to promote good health, comradeship and a spirit of friendly competition, which, in turn, has positive impact on the overall development of personality of the youth. Excellence in sports enhances the sense of achievement, national pride and patriotism. Sports also provide beneficial recreation, improve productivity and foster social harmony and discipline'. 228 The discipline and social cohesion factors feature strongly here, as in Singapore, and add weight to the notion that state sponsored programmes to encourage groups to participate in sports is beneficial for the socio-cultural development of the growth. Moreover, there is an implicit indication that such measures are achievable, and therefore cross over from being a good intention to being a policy that can produce the prescribed outcomes.

A component in this policy is what is known as 'broadbasing, which effectively is a coordinated and extremely comprehensive approach to ensuring popular participation in sports is maximised. This policy has been implemented in India, and is summarised as follows: 'Considering the key role of sports in national life and for inculcating national pride in the younger generation, the objective of broad basing, that is, universalisation or mass participation in Sports assumes special significance. It is imperative to ensure that the educational institutions, Schools and Colleges in both rural and urban areas; the Panchayati Raj Institutions, Local Bodies, the government machinery, the Sports Associations and Industrial Undertakings, as also the various Youth and Sports Clubs, including those of the Nehru Yuva Kendra Sangathan (NYKS) throughout the country are, and remain, fully associated with this Programme. Efforts will be made to promote and encourage women's participation $\mathrm{n}$ sports. The Union and State Governments, as well as the Sports Federations/Associations will endeavour to promote a "club 
culture" for the speedier development of Sports in the country'.229

The Government of Ontario, Canada, has a comparable policy of encouraging the involvement of its population in sports '...for the health, social, and economic benefit of Ontarians and the communities in which they live'. ${ }^{230}$ Its model for achieving this has been a multi-faced one. First, an endowment fund was established to assist '...local community recreation partners, through Community Foundations, to develop quality recreation programs that promote safe and supportive recreation activities, help children and youth develop good social skills, improve school performance and avoid negative behaviour'. In addition to this, a Recreation Development Fund was formed, which '....aimed at encouraging projects that will increase physical activity and expand local sport opportunities to meet the recreation needs of their residents'. Furthermore, the Ontario Government initiated a plan whereby funding and planning advice would be made available to help amateur sport organisations become more self-reliant. Finally, an awards programme was instituted '...to honour and promote athletic achievement and participation in sport and fitness. The awards annually recognize athletes and coaches who have distinguished themselves nationally or internationally in the previous year, as well as corporate sponsors and volunteers who have contributed to the development of Ontario amateur sports. Ontario Sports Awards are given in the following categories: Team of the Year; Athlete with a Disability; Male Athlete of the Year; Female Athlete of the Year'.231 A similar award system in New Zealand - the Maori Sports Awards - serves some of these functions, although in the Ontario case study, the awards regime is simply a component in a much broader strategy for encouraging involvement of the local population in sporting activities.

In England, Sports England developed a limited strategic approach to encouraging sports involvement. The strategy 
focussed on Government support for extending the range of facilities offering by existing sporting institutions, working through higher education institutions as one of the 'bridges' between Government and the community, and the establishment of partnerships with various community groups. This approach could well be tailored for New Zealand, with sporting policy looking more closely at opportunities of working with marae and Maori authorities to further levels of Maori participation in sports. ${ }^{232}$

The Council of Europe, in developing a long-term strategy on encouraging greater popular participation in sporting activity, recommends that 'Due account should be taken of the potential of team games to encourage children to engage in various social roles and thus develop their ethical and social consciousness and their sense of responsibility in social relations'.233 In its vision, the distinct cultural nuances of the member countries of the Council of Europe receive no recognition. The traits of fair play, 'social co-operation and integration and peace',234 and the health and economic benefits of sport involvement effectively preclude the role of cultural reinforcement. Indeed, the tenor of the Council's policies suggests that individual cultural preferences have no role in the future of European sporting activity. This is significant for Maori participation in sports in New Zealand, and the planning that accompanies strategies to increase involvement, because it illustrates the need for a distinct cultural dimension of the planning to be taken into consideration.

Overall, the international approaches to improving the participation of communities in porting activities can be separated into two main categories. The first is of those which concentrate almost exclusively on the immediate health and social benefits of sports participation. The second category possesses definite agendas of cultural promotion and enhancement. The latter course would most likely be 


\section{appropriate for any policy promoting greater Maori sports} involvement in New Zealand.

\section{Note}

1 The American Heritage Dictionary of the English Language, Fourth Edition, Boston, 2000.

2 Hillary Commission, Report of the Maori Taskforce on Sport, Fitness and Leisure, 1998, Wellington, 1998, p. 9.

3 C. R. Edginton, C. J. Hanson, S. R. Edginton, Leisure Programming: Concepts, Trends, and Professional Practice, Second Edition, Dubuque, 1992, p. 4.

4 R. Walker, Ka Whawhai Tonu Matou: Struggle Without End, Auckland, 1990, p. 63.

5 T. Moeke-Pickering, Maori Identity within Whanau: A Review of Literature, Master of Social Science Thesis, University of Waikato, Hamilton, 1996; H. M. Mead, Tikanga Maori: Living by Maori Values, Wellington, 2003.

6 I. Pool, Te Iwi Maori : A New Zealand Population, Past, Present \& Projected, Auckland, 1991.

7 I. Van Aalst, D. Kazakov, and G. McLean, SPARC Facts: Results from the New Zealand Sport and Physical Activity Survey 1997 - 2001, Wellington, 2003.

Ibid., p. 3.

Ibid., p. 4.

Ibid., p. 13.

Ibid., p. 20.

Ibid., p. 27.

Ibid., p. 30.

Ibid., p. 33.

Sport and Recreation New Zealand, SPARC Facts, Wellington, 2001, p. 6.

Op. cit.

R. Walker, Ka Whawhai Tonu Matou: Struggle Without End, Auckland, 1990; J. Metge, Rautahi: the Maoris of New Zealand, London, 2004; A. M. Corbett, The Experience of Whanau Caring for Members Disabled from the Effects of Stroke, MPhil Thesis, Massey University, Palmerston North, 2003; H. M. Mead, Tikanga Maori: Living by Maori Values, Wellington, 2003.

18 T. Moeke-Pickering, 'Maori Identity Within Whanau: A Review of Literature', University of Waikato, Hamilton, 1996.

19 M. H. Durie, 'Whanau/Families and Healthy Development', Paper Presented to the Fifth Annual Conference of the New Zealand College of Clinical Psychologists, Hamilton, 1994.

20 T. Moeke-Pickering, 'Maori Identity Within Whanau: A Review of Literature', p. 1 .

21 M. H. Durie, 'Whanau/Families and Healthy Development'.

22 T. Moeke-Pickering, 'Maori Identity Within Whanau: A Review of Literature', p. 1 .

23 R. Walker, 'Maori Identity', in D. Novitz and B. Willmott, (eds. ), Culture and Identity in New Zealand, Wellington, 1989.

24 C. Barlow, Tikanga Whakaaro - Key Concepts in Maori Culture, Auckland, 1991; M. H. Durie, 'Whanau/Families and Healthy Development'.

25 J. Broughton, 'Being Maori', in New Zealand Medical Journal, Vol. 106, No. 968, 1993, pp. 506-508; J. Rangihau, 'Being Maori', in M. King (ed.), Te Ao Hurihuri, Auckland, 1977. 
T. Moeke-Pickering, 'Maori Identity Within Whanau: A Review of Literature', p. 1.

27 J. Rangihau, 'Being Maori', in T. Moeke-Pickering, 'Maori Identity Within Whanau: A Review of Literature', p. 1.

28 R. Walker, 'Maori Identity'.

29 M. Bennett, 'Te Kupu Whakamutunga: The Last Word', in New Zealand Planning Council, He Matapuna: A Source, Wellington, 1979, pp. 74-79.

30 R. Parata, 'Attitudes', in New Zealand Planning Council, Puna Wairere Essays by Maori, Wellington, 1990.

31 T. Karetu, 'The Clue to Identity', in New Zealand Geographic, Vol. 5, 1990, pp. 112-112.

32 M. H. Durie, T. E. Black, I. S. Christensen, A. E. Durie, U. K. Taiapa, U. K. J. Potaka, and E. Fitzgerald, Te Hoe Nuku Roa Framework - A Maori Identity Measure', in Association of Social Science Researchers, ASSR News, October, 1995.

33 T. Moeke-Pickering, 'Maori Identity Within the Whanau: A Review of the Literature', p. 4.

34 Op. cit.

35 R. Walker, 'Maori Identity'.

36 L. W. Nikora, 'Race, Culture and Ethnicity - Organisation of Maori Social Groups', in L. W. Nikora and T. M. Moeke-Pickering (eds.), Maori Development and Psychology, Hamilton, 1995, pp. 20-24.

37 R. Walker, 'The Urban Maori', in New Zealand Planning Council, He Matapuna: A Source, Wellington, 1979, p. 37.

38 Public Health Commission, Our Health, Our Future: Hauora Pakari, Koiora Roa: The State of Public Health in New Zealand 1993, Wellington, 1993, pp. 56-58.

39 M. H. Durie, T. E. Black, I. S. Christensen, A. E. Durie, U. K. Taiapa, U. K. J. Potaka, and E. Fitzgerald, Te Hoe Nuku Roa Framework - A Maori Identity Measure',

40 T. Moeke-Pickering, 'Maori Identity Within the Whanau: A Review of the Literature', p. 4.

41 K. Quinn, 'It's The Whanau Feeling', in Mana Magazine, Vol. 1, 1993,p. 44.

42 T. Moeke-Pickering, 'Maori Identity Within the Whanau: A Review of the Literature', p. 4.

43 M. Durie, 'Maori Development: Reflections and Strategic Directions', A paper presented at Toi Te Kupu, Toi Te Mana, Toi Te Whenua Conference on Maori Development in a Global Society held at Putahi-a-Toi, School of Maori Studies, Massey University, Palmerston North 4 - 6 July 2000, reproduced in He Pukenga Korero, Vol. 5, No. 1, Palmerston North, 2000.

44 G. Harmsworth, 'Indigenous concepts, values and knowledge for sustainable development: New Zealand case studies', in 7th Joint Conference: Preservation of Ancient Cultures and the Globalization Scenario, School of Maori and Pacific Development \& International Centre for Cultural Studies (ICCS), India, 22 - 24 November 2002, Te Whare Wananga o Waikato, University of Waikato, Hamilton, 2002.

45 P. White, 'Restoration of the Tribal Collective: Rebuilding Tribal Capacity Alongside Economic Development', A paper presented at Toi Te Kupu, Toi Te Mana, Toi Te Whenua Conference on Maori Development in a Global Society held at Putahi-a-Toi, School of Maori Studies, Massey University, Palmerston North $4-6$ July 2000, reproduced in He Pukenga Korero, Vol. 5, No. 2. Palmerston North, 2000, pp. 41-44.

46 G. Harmsworth, Indigenous concepts, values and knowledge for sustainable development: New Zealand case studies', p. 4. 
47 S. Palmer, 'Homai te Waiora ki Ahau: A Tool for the Measurement of Wellbeing Among Maori - the Evidence of Construct Validity', in New Zealand Journal of Psychology, July, 2004.

48 Op. cit.; A.C. Acock and J.S. Huribert, 'Social networks, marital status and wellbeing', in Social Networks, Vol. 15, No. 3, 1993, pp.309-334; P. BlackOlien, 'The effects of prenatal programs on postpartum emotional wellbeing', in Social Behaviour and Personality, Vol. 21, No. 3, 1993, pp. 169-174; A. Bowling, Measuring Health: A Review of Quality of Life Measurement Scales, Buckingham, 1991; I.A. Connidis and J.A. McMullin, 'To have or have not: Parent status and the subjective wellbeing of older men and women', in Gerontologist, Vol. 33, No. 5, 1993, pp. 630-636; R. Flett, 'Subjective wellbeing: Its measurement and correlates'. Unpublished Thesis, PhD, Department of Psychology, University of Otago, Dunedin, 1986; M.M. Friedman, 'Social support sources and psychological wellbeing in older women with heart disease', in Research in Nursing and Health, Vol. 16, 1993, pp. 405-413; T.A. Judge, \& C.L. Hulin, 'Job satisfaction as a reflection of disposition: A multiple source causal analysis', in Organisational Behaviour and Human Decision Processes, Vol. 56, No. 3, 1993, pp. 388-421; D. J. Rodd, 'Psychological wellbeing and stress in mothers of young children', in Australian Journal of Early Childhood, Vol. 19, No. 2, 1994, pp. 3-9; A.B. Sistler and F. Blanchard-Fields, 'Being in control: A note on differences between caregiving and non-caregiving spouses', in Journal of Psychology, Vol. 127, No. 5, 1993, pp. 537-542; S. Zika and K. Chamberlain, 'On the relation between meaning in life and psychological wellbeing', in British Journal of Psychology, Vol. 83, 1992, pp. 133-145; R. Kammann, 'Objective circumstances, life satisfaction and sense of wellbeing: consistencies across time and place', in New Zealand Journal of Psychology, Vol. 12, 1983, pp. 14-22.

49 S. Palmer, 'Homai te Waiora ki Ahau: A Tool for the Measurement of Wellbeing Among Maori - the Evidence of Construct Validity', p. 2.

50 Royal Commission on Social Policy, The April Report of the Royal Commission on Social Policy, Vols. I-IV, Wellington, 1988.

51 S. Palmer, 'Homai te Waiora ki Ahau: A Tool for the Measurement of Wellbeing Among Maori - the Evidence of Construct Validity', p. 2; R. Pere, Te Wheke - A Celebration of Infinite Wisdom, Gisborne, 1991.

52 Te Roopu Awhina o Tokanui, 'Cultural Perspectives in Psychiatric Nursing: A Maori Viewpoint', Paper presented to the Australian Congress of Mental Health Nurses, 12th National Convention, Adelaide, 1986; C. Barlow, Tikanga Whakaaro. Key Concepts in Maori Culture. Auckland, 1991; H. Barrett-Aranui, 'Nga matapihi o te waiora', in A. Munro, B. Manthei, and J. Small, (eds.), Counselling: the Skills of Problem Solving. Auckland, 1981; M. Durie, E. Fitzgerald, T. K. Kingi, S. McKinley, and B. Stevenson, Te Hoe Nuku Roa. Maori Specific Outcomes and Indicators. A Report Prepared for Te Puni Kokiri', in Te Putahi a Toi, Massey University, Palmerston North, 2002; J. Rangihau, 'Being Maori'; T. W. Pohatu and H.R. Pohatu, 'Mauri rethinking human wellbeing', unpublished paper, Auckland University of Technology, Auckland, 2003.

53 S. Palmer, 'Homai te Waiora ki Ahau: A Tool for the Measurement of Wellbeing Among Maori - the Evidence of Construct Validity', p. 2.

54 G. HARMSWORTH, 'INDIGENOUS CONCEPTS, VALUES AND KNOWLEDGE FOR SUSTAINABLE DEVELOPMENT: NEW ZEALAND CASE STUDIES'.

55 Ibid., pp. 2-3.

56 Ibid., p. 3. 
57 Creative New Zealand, 'Understanding Cultural Well-Being', Presentation to Local Government New Zealand Conference, Queenstown, July, 2003.

58 Op. cit.

59 G. R. Harmsworth, R. Barclay, K. Kerr, and T. Reedy, 'Maori Sustainable Development in the 21st Century: The importance of Maori values, strategic planning, and information systems', in He Puna Korero, Journal of Maori and Pacific Development, University of Waikato, Hamilton, 2002.

60 J. Maguire, in J. Maguire, (ed.), Power and Global Sport: Zones of Prestige, Emulation and Resistance, London, 2005, p. 1.

61 R. W. Thomson, 'Maori Myths and Legends: Physical Activity and Games of Early Maori', Journal of Sport Behavior, Vol. 1, No. 1, 1978, pp. 42-48.

62 E. Best, Games and Pastimes of the Maori, Wellington, 1925.

63 Report of the Sport, Fitness and Leisure Ministerial Taskforce, Getting Set for an Active Nation, Wellington, 2001, p. 17.

64 R. W. Thomson, 'Maori Myths and Legends: Physical Activity and Games of Early Maori'.

65 Report of the Sport, Fitness and Leisure Ministerial Taskforce, Getting Set for an Active Nation, p. 17.

66 J. Holliman, American Sport, New York, 1975, in J. Barclay, 'An Analysis of Trends in New Zealand Sport from 1840 to 1900', BA Honours Thesis, Massey University, Palmerston North, 1977, p. 6.

67 J. Miller, Early Victorian New Zealand, Oxford University Press, London, 1958 , p. 166.

68 A. Sutherland, New Zealand Famous Firsts and Related Records, Auckland, 1961, p. 95.

69 Cited in G. Inglis, Sport and Pastime in Australia, Sydney, 1912, p. 8.

$70 \mathrm{~J}$. Barclay, 'An Analysis of Trends in New Zealand Sport from 1840 to 1900 ', p. 11.

71 Hillary Commission, Report of the Maori Taskforce on Sport, Fitness and Leisure, 1998, p. 16

72 BBC Sport, Uncovering the Maori Mystery, London, 5 June 2003.

73 Canterbury Times, 1882, in G. Slatter, Great Days at Lancaster Park, Christchurch, 1974, pp. 86-7.

74 E. Best, Games and Pastimes of the Maori, p. 104.

75 Report of the Sport, Fitness and Leisure Ministerial Taskforce, Getting Set for an Active Nation, p. 18.

76 Ibid., p. 20.

77 J. Phillips, 'The Hard Man: Rugby and the Formation of Male Identity in New Zealand', in J. Nauright and T. J. L. Chandler (eds.), Making Men: Rugby and Masculine Identity, London, 1986, pp. 86 and 88.

78 M. Volkerling, 'Sport as Culture: Passion and Possibility', p. 69.

79 E. Best, Games and Pastimes of the Maori, p. 102.

80 B. Sutton-Smith, 'The Meeting of Mari and European Cultures and its Effects upon the Unorganised Games of Maori Children', in Journal of the Polynesian Society, Vol. 60, 1951, p. 95.

81 J. Barclay, 'An Analysis of Trends in New Zealand Sport from 1840 to 1900 ', p. 9.

82 T. Locke, The Indigenous Pakeha: An Interview with Michael King, Waikato University, Hamilton, 2005.

83 J. Strutt, 1801, in J. Barclay, 'An Analysis of Trends in New Zealand Sport from 1840 to 1900 ', p. 5.

84 H. W. Morton, Soviet Sport, New York, 1963, p. 13.

85 F. W. Cozens and F. S. Stumpf, Sports in American Life, Chicago, 1953, p. 1 . 
B. Dobbs, Edwardians at Play, London, 1973, p. 25.

Massey University, Department of Marketing, Summary Report on Survey of National Identity, Palmerston North, 1997.

M. Volkerling, 'Sport as Culture: Passion and Possibility', in C. Collins (ed.), Sport in New Zealand Society, Palmerston North, 2000, p. 66; New Zealand Olympic and Commonwealth Games Association, Review of Strategy and Communications: Report to the Olympic and Commonwealth Games Associations, Wellington, 1995; B. Gidlow, G. Cushman, and H. Perkins, "Whatever Happened to "Recreation"? Changes in New Zealand State Leisure Policy', in ANZALS Leisure Research Series, Vol. 2, 1995, pp. 76-94. J. K. Baxter, 'Introduction', in C. Doyle (ed.), Recent Poetry in New Zealand, Auckland, 1965, p. 30.

M. Volkerling, 'Sport as Culture: Passion and Possibility', p. 66.

R. S. Kretschmar, Practical Philosophy of Sport, Illinois, 1994.

M. Volkerling, 'Sport as Culture: Passion and Possibility', p. 68; R. Williams, Keywords: A Vocabulary of Culture and Society, Glasgow, 1976, p. 77.

M. Arnold, Culture and Anarchy, Cambridge, 1960, p. 6.

A. L. Kroeber and C. Kluckhohn, Culture: A Critical Review of Concepts and Definitions, Harvard, 1952, p. 334.

C. Geertz, The Interpretation of Cultures, London, 1973, p. 5.

A. Swidler, 'Culture in Action: Symbols and Strategies', in American Sociological Review, Vol. 1, April 1986, p. 273.

A. Jamzorik, C. Boland, R. Urquhart (eds.), Social Change and Cultural Transformation in Australia, Cambridge, 1995, p. 31.

M. Volkerling, 'Sport as Culture: Passion and Possibility', p. 68.

F. H. Tenbruck, 'The Cultural Foundation of Society', in H. Haferkamp (ed.), Social Structure and Culture, Berlin, 1989, p. 32.

D. Grey and S. Greben, 'Wanted: A New Word for Recreation', in Parks and Recreation, Vol. 9, No. 3, New York, 1979, p. 23.

M. Kaplan, Leisure Theory and Policy, New York, 1975, p. 19.

J. Dumazadier, Sociology of Leisure, New York, 1974, p. 37.

E. Snyder and E. Spreitzer, Social Aspects of Sports, Englewood Cliffs, 1978, p. 160.

M. Volkerling, 'Sport as Culture: Passion and Possibility', p. 69.

M. R. Real, Mass-Mediated Culture, Englewood Cliffs, 1976, p. 27.

J. F. Murphy, Concepts of Leisure: Philosophical Implications, New Jersey, 1974 , p. 6.

J. B. Nash, Philosophy of Recreation and Leisure, Dubuque, 1960, p. 89.

C. R. Edginton, C. J. Hanson, S. R. Edginton, Leisure Programming: Concepts, Trends, and Professional Practice, p. 8.

D. M. Samdahl, Leisure in Our Lives: Exploring the Common Formulation of Leisure Theory, New York, 1992.

J. Hutchinson, 1951, in C. R. Edginton, C. J. Hanson, S. R. Edginton, Leisure Programming: Concepts, Trends, and Professional Practice, p. 10.

P. L. Driver and G. L. Peterson, Benefits of Outdoor Recreation: An Integrating Overview, Washington, 1986.

Op. cit.

M. Daum and G. Getzel, 'Preference for Age-Homogenous Versus AgeHeterogeneous Social Interaction', Paper presented at the Thirty-Third Annual Scientific Meeting of the Gerontological Society of America, 1980; L. Harris The Myth and Reality of Aging in America, Washington, 1975; C. Seefeldt, R. D. Jantz, K. Serock, and S. Bredekamp, Elderly Persons' Attitudes Toward Children, Maryland, 1979. 
114 M. J. Leitner and S. F. Leitner, Leisure in Later Life, Third Edition, New York, 2004, p. 201.

115 Op. cit.; D. Leviton and L. Santa Maria, 'The Adults' Health and Development Program: Descriptive and Evaluative Data', in Gerontologist, Vol. 19, No. 6, 1979, pp. 534-543; P. Meier, Toddlers, Elderly Share Quarters at Day Care Centre', in Senior Citizens Day Care News, Vol. 1, No. 1, 1980, p. 5; U. Chowhary, C. Schultz, P. Hasselriis, H. Kujath, P. Penn, and S. Henson, 'Intergenerating Activities and Aging Appreciation of Elementary School Children', in Educational Gerontology, Vol. 26, No. 6, 2000, pp. 541-549; L. J. Knapp and P. Stubblefield, 'Changing Students' Perceptions pf Aging: The Impact of an Intergenerational Service :earning Course', in Educational Gerontology, Vol. 26, No. 7, 2000, pp. 611-622; M. Pinquart, S. Wenzel, and S. Sorensen, 'Changes in Attitudes Among Children and Elderly Adults in Intergenerational Group work', in Educational Gerontology, Vol. 26, No. 6, 2000, pp. 523-531; Rothstein, 'What Toddlers Need: Graying Boomers', in New York Times, 1 March 2000, p. A22; M. J. Keller, 'Linking Generations Through Recreation', in Parks and Recreation, March 1992, pp. 59-60.

116 M. J. Leitner and S. F. Leitner, Leisure in Later Life, p. 439.

117 Y. Harhousou, 'Elderly People, Leisure and Physical recreation in Greece', in World Leisure and Recreation, Vol. 41, No. 3, 1999, pp. 20-24; M. Leitner and G. Scher, 'A Follow-up Study to Peace-Making: The Positive Effects of Intergenerational Activities on the Attitudes of Israeli Arabs and Jews Toward Each other', in World Liesure and Recreation, Vol. 41, No. 2, 2000, pp. 25-29; I. L. Prakash, 'Senior Women's Perception of Liesure in India', in Tourism Recreation Research, Vol. 24, No. 1, 1999, pp. 82-85.

118 J. Levy, 'Leisure and Retirement in the New Age Wave Society', in World Leisure and Recreation, Vol. 34, No. 1, 1992, pp. 5-9; R. Kubey, 'The Aging Aquarius', in This World, 2 April 1989, pp. 9-12.

119 M. Volkerling, 'Sport as Culture: Passion and Possibility', p. 70.

120 A. Blake, The Body Language: The Meaning of Modern Sport, London, 1996, p. 24.

121 J. McClancy, 'Sport, Identity and Ethnicity', in J. McClancy (ed.), Sport, Identity and Ethnicity, Oxford, 1996, p. 5.

122 M. Volkering, 'Sport as Culture: Passion and Possibility', p. 72.

123 R. L. Simon, Sport and Moral Values, Oxford, 1991, p. 200, in M. Volkering, 'Sport as Culture: Passion and Possibility', p. 72.

124 M. Csikszentmihalyi, Optimal Experience: Psychological Studies of Flow in Consciousness, Cambridge, 1988, p. 30.

125 M. Volkering, 'Sport as Culture: Passion and Possibility', p. 73.

126 N. Mtsweni, MEC for Culture, Sport \& Recreation, speech at the budget vote 2005/2006, Issued by: Department of Culture, Sport \& Recreation, Mpumalanga Provincial Government, South Africa, 19 April 2005.

127 Government of South Africa, Reconstruction and Development Programme 1994, Cape Town, 1994, in N. Mtsweni, MEC for Culture, Sport \& Recreation, speech at the budget vote 2005/2006, 19 April 2005.

128 T. Mbeki, in South African Sports Commission, 'North West to host the best of the best event on Indigenous Games', Cape Town, 4 March 2005.

129 J. Phaahla, in South African Sports Commission, 'North West to host the best of the best event on Indigenous Games', Cape Town, 4 March 2005.

130 Department of Local Government, Planning, Sport and Recreation, The State of Queensland, Remote and Indigenous hockey case study, Queensland, September 2004. 
131 North American Indigenous Games, 'Mission Statement', Cornwall Island, 2005.

North American Indigenous Games, 'The Spirit: Strong, Brave and True', Cornwall Island, 2005.

133 Te Puni Kokiri, Omangia To Oma Roa: Maori Participation in Physical Leisure, Wellington, 1995, pp. 10-11.

S. Hemming and D. Rigney, 'Adelaide Oval: A Postcolonial 'Site'?', in Borderlands Vol. 2, No. 1, Adelaide, 2003.

Op. cit.

136 J. Nauright, Sport, Cultures and Identities in South Africa, London, 1997, p. 191.

S. Hemming and D. Rigney, 'Adelaide Oval: A Postcolonial 'Site'?'.

Op. cit.

Op. cit.

Jarvie, Class, Race and Sport in South Africa's Political Economy, London, 1985; G. Jarvie, Sport, Racism and Ethnicity, London, 1991; G. Sage, Power and Ideology in American Sport: A Critical Perspective, Illinois, 1990.

S. Birrell 'Racial Relations Theories and Sport: Suggestions for a More Critical Analysis', in Sociology of Sport Journal, Vol. 6, 1989, p. 219.

In reference to the Australian experience, see, see D. Byrne, 'Deep nation: Australia's acquisition of an indigenous past', in Aboriginal History, Vol. 20, 1996, pp. 82-107; G. Macdonald, 'Master narratives and the dispossession of the Wiradjuri' in Aboriginal History, Vol. 22, 1998, pp. 162-179; S. Hemming, S. Wood, and R. Hunter, Richard (2000) 'Researching the past: oral history and archaeology at Swan Reach' in R. Torrens, and A. Clarke (eds.), The Archaeology of Difference: Negotiating Cross-Cultural Engagements in Oceania, London, 2000, pp. 331-359. H. Bhabha, Location of Culture, London, 1994. Swanbury Penglase Architects, The Adelaide Oval Conservation Plan 2001: Report for South Australian Cricket Association, Adelaide, 2001. M. Brown and R. Taylor, Adelaide Oval Conservation Plan for the SACA, Hassell Architects, Adelaide, August 1991. J. Nauright, Sport, Cultures and Identities in South Africa, p. 189. The same can be said for the relationship between history, Indigenous 'culture' and the heritage industry, see G. Davison, Graeme, "The Meanings of "Heritage", in G, Davison, and C. McConville (eds.), A Heritage Handbook, Sydney, 1994, p. 6.

147 S. Hemming and D. Rigney, 'Adelaide Oval: A Postcolonial 'Site'?'.

148 D. Lowenthal, The Heritage Crusade and the Spoils of History, Cambridge, 1998.

J. Nauright, Sport, Cultures and Identities in South Africa, p. 190.

Op. cit.

151 J. Baudrillard, Jean, Simulacra and Simulation, Michigan, 1994.

152 M. Keith and S. Pile, 'Introduction', in M. Keith and S. Pile (eds.), Place and the Politics of Identity, London, 1993, p. 9.

S. Hemming and D. Rigney, 'Adelaide Oval: A Postcolonial 'Site'?'.

154 J. Maguire, in J. Maguire, (ed.), Power and Global Sport: Zones of Prestige, Emulation and Resistance, London, 2005, p. 2.

155 D. Godwell, 'Playing the game: Is sport as good for race relations as we'd like to think?', in Australian Aboriginal Studies, Vol. 1, Canberra, 2000. J. Entine, 'Questions of Race', in Philadelphia Magazine, January 2000.

D. McCarthy, R. L. Jones, P. Potrac, 'Constructing Images and Interpreting Realities: The Case of the Black Soccer Player on Television', in International Review for the Sociology of Sport, Vol. 38, No. 2, 2003, pp. 217-238. 

1990s', in Northeastern University, Sport in Society, Boston, 2004, p. 1. Op. cit.

160 Op. cit.

161 H. Edwards, in J. Entine, Taboo: Why Black Athletes Dominate Sports and Why We Are Afraid to Talk About It, New York, 2000. Afraid to Talk About It, New York, 2000. J. Hoberman,

C. Murray and D. D'Souza, in J. Hoberman, Darwin's Athletes: How Sport has Damaged Black America and Preserved the Myth of Race, New York, 1997.

J. Hoberman, Race and Sport: The Social Costs of "Black Dominance".

168 M. Volkering, 'Sport as Culture: Passion and Possibility', p. 73.

169 J. Atkinson, 'Cup Fever', in North and South, July, 1995, p. 43.

170 M. Volkering, 'Sport as Culture: Passion and Possibility', p. 73.

D. Whitson, 'Circuits of Promotion: Media, Marketing and the Globalization of Sport', in L. A. Werner (ed.), MediaSport, London, 1998, p. 65.

J. McGregor, 'The Mass Media and Sport', in C. Collins (ed.), Sport in New Zealand Society, p. 188.

R. Rowe, 'Wall-to-Wall World of Sport', in Media Information Australia, Vol. 71,1995, p. 3.

J. McGregor, 'Media Sport', in L. Trenberth and C. Collins (ed.), Sport Management in New Zealand: An Introduction, Palmerston North, 1994.

K. C. Schroder, 'Cultural Quality: Search for a Phantom? A Reception Perspective on Judgements of Cultural Value, in M. Skovmand and K. M. Schroder (eds.), Media Cultures: Reappraising Transnational Media, London, 1992, p. 206. M. Volkering, 'Sport as Culture: Passion and Possibility', p. 74.

178 Op. cit.

179 Ibid., p. 75.

180 E. Cashmore, Making Sense of Sports, London, 1990, p. 87, in M. Volkering, 'Sport as Culture: Passion and Possibility', p. 75. 56.

182 S. Thompson, P. Rewi, and D. Wrathall, 'Maori Experiences in Sport and Physical Authority: Research and Initiatives', in C. Collins (ed.), Sport Management in New Zealand: An Introduction, p. 246. Op. cit.

184 New Zealand Sports Foundation, Five Year Plan: New Zealand Sports Foundation, Wellington 1996, p. 1. Collins, Sport in New Zealand Society, pp. 115-6.

186 J. Coakley, Sport in Society: Issues and Controversies, Boston, 1998.

187 R. McConnell and M. Edwards, 'Sport and Identity in New Zealand', p. 117.

188 J. MacClancy, Sport, Identity and Ethnicity, Oxford, 1996, pp. 2-3.

189 R. McConnell and M. Edwards, 'Sport and Identity in New Zealand', p. 117.

190 J. MacClancy, Sport, Identity and Ethnicity, pp. 2-3.

191 Op. cit.

192 Op. cit. 
Op. cit.

Op. cit.

Ibid., pp. 248-9.

Ibid., p. 249.

J. J. Coakley, Sport in Society, Boston, 1998.

S. Thompson, P. Rewi, and D. Wrathall, 'Maori Experiences in Sport and Physical Authority: Research and Initiatives', pp. 250-1.

J. J. Coakley, Sport in Society, Boston, 1998, p. 253.

R. Lapchick, Racial Report Card, Boston, 1996; C. J. Hallanan, 'Aborigines and Positional Segregation in Australian Rugby League', in International Review for the Sociology of Sport, Vol. 26, No. 2, 1988, pp. 69-78; J. Maguire, 'Race and Position Assignment in English Soccer: A Preliminary Analysis of Ethnicity and Sport in Britain', in Sociology of Sport Journal, Vol. 5, No. 3, 1988, pp. 257-269.

M. J. Melnick, 'Maori Women and Positional Segregation in New Zealand Netball: Another Test of the Anglocentric Hypothesis', in Sociology of Sport Journal, Vol. 13, 1996, pp. 259-273; M. J. Melnick and R. Thomson, 'The Maori People and Positional Segregation in New Zealand Rugby Football: A Test of the Anglocentric Hypothesis', in International Review for Sociology of Sport, Vol. 31, No. 2, 1996, pp. 139-153. S. 9, State Owned Enterprise Act 1987.

B. Biggs, 'Humpty-Dumpty and the Treaty of Waitangi', in I. H. Kawharu (ed.), Waitangi: Maori and Pakeha Perspectives on the Treaty of Waitangi, Auckland,1989, p. 308.

R. McConnell, 'Maori, The Treaty of Waitangi and Sport: A Critical Analysis', in C. Collins, (ed.), Sport Management in New Zealand: An Introduction, p. 232.

Op. cit. Governing Bodies of Sport, Fitness and Leisure, Wellington, 1998-1999.

R. McConnell, 'Maori, The Treaty of Waitangi and Sport: A Critical Analysis', p. 233.

209 Op.cit.

210 P. Spoonley, Racism and Ethnicity, Auckland, 1988.

211 R. McConnell, 'Maori, The Treaty of Waitangi and Sport: A Critical Analysis', p. 233.

212 Ibid., p. 235.

213 G. Henshall, Encouraging Participation in Active Leisure, Melbourne, 2001.

214 Sport Auckland, He Oranga Poutama, Auckland, 2003.

215 Ministry of Health, DHB Toolkit: Physical Activity to Increase Physical Activity, Wellington, 2003, p. 28.

216 Te Puni Kokiri, Omangia te Oma Roa: Maori Participation in Physical Leisure, Wellington, 1995.

217 Op. cit.

218 Ministry of Health, DHB Toolkit: Physical Activity to Increase Physical Activity, p. 28.

219 Op. cit.

220 Op. cit.

221 P. Bergin, 'Maori Sport and Cultural Identity in Australia', in The Australian Journal of Anthropology, Volume 13, Number 3, December 2002, pp. 257269.

222 Op. cit.

223 Speers Sports Club, Administration, Bankstown, 2005. 
Op. cit.

Op. cit.

R. T. M. Kirk, 'The Regulation of Sports in Singapore', in Focus, Singapore, December 2002.

227 Op. cit.

228 Ministry of Youth Affairs and Sports, National Sports Policy 2001, New Delhi, 2001, p.1.

229 Ibid., p. 2.

230 Government of Ontario, Sport and Recreation, March 2004, p. 1.

231 Ibid., pp. 2-4.

232 Sport England, Higher Education and Sport in England, March 2004, pp. 26.

233 Council of Europe, Recommendation on the Significance of Sport for Society, Ref. (95/17), Lisbon, 1995.

234 Op. cit. 